\title{
T Cells Limit Accumulation of Aggregate Pathology Following Intrastriatal Injection of $\alpha$-Synuclein Fibrils
}

\author{
Sonia George $^{\mathrm{a}, *}$, Trevor Tyson ${ }^{\mathrm{a}}$, Nolwen L. Rey ${ }^{\mathrm{a}, \mathrm{b}}$, Rachael Sheridan ${ }^{\mathrm{c}}$, Wouter Peelaerts ${ }^{\mathrm{a}}$, \\ Katelyn Becker ${ }^{\mathrm{a}}$, Emily Schulz ${ }^{\mathrm{a}}$, Lindsay Meyerdirk ${ }^{\mathrm{a}}$, Amanda R. Burmeister ${ }^{\mathrm{a}}$, \\ Christian U. von Linstow ${ }^{\mathrm{a}}$, Jennifer A. Steiner ${ }^{\mathrm{a}}$, Martha L. Escobar Galvis ${ }^{\mathrm{a}}$, Jiyan Ma ${ }^{\mathrm{a}}$, \\ J. Andrew Pospisilik ${ }^{\mathrm{d}}$, Viviane Labrie ${ }^{\mathrm{a}, \mathrm{e}, \dagger}$, Lena Brundin $^{\mathrm{a}, \mathrm{e}}$ and Patrik Brundin ${ }^{\mathrm{a}, \mathrm{e}}$ \\ ${ }^{a}$ Center for Neurodegenerative Science, Van Andel Institute, Grand Rapids, MI, USA \\ ${ }^{\mathrm{b}}$ Laboratory of Neurodegenerative Diseases, Institut François Jacob, MIRCen, CEA, CNRS, Fontenay-aux-Roses, \\ France \\ ${ }^{\mathrm{c}}$ Flow Cytometry Core Facility, Van Andel Institute, Grand Rapids, MI, USA \\ ${ }^{\mathrm{d}}$ Center for Epigenetics, Van Andel Institute, Grand Rapids, MI, USA \\ ${ }^{\mathrm{e}}$ Michigan State University - College of Human Medicine, Department of Psychiatry, Grand Rapids, MI, USA
}

Accepted 18 January 2021

Pre-press 11 February 2021

\begin{abstract}
. evidence that these cells can be key to the pathogenesis of the disease. PFF-injected immunocompromised mice. microglia \footnotetext{
ative Science, Van Andel Institute, 333 Bostwick Ave., N.E., Grand Rapids, MI 49503, USA. Tel.: +1 616234 5000; E-mail: sonia.george@vai.org.

${ }^{\dagger}$ Deceased.
}

*Correspondence to: Sonia George, Center for Neurodegener-
\end{abstract}

Background: $\alpha$-Synuclein $(\alpha$-syn) is the predominant protein in Lewy-body inclusions, which are pathological hallmarks of $\alpha$-synucleinopathies, such as Parkinson's disease (PD) and multiple system atrophy (MSA). Other hallmarks include activation of microglia, elevation of pro-inflammatory cytokines, as well as the activation of $\mathrm{T}$ and $\mathrm{B}$ cells. These immune changes point towards a dysregulation of both the innate and the adaptive immune system. $\mathrm{T}$ cells have been shown to recognize epitopes derived from $\alpha$-syn and altered populations of T cells have been found in PD and MSA patients, providing

Objective To study the role of the adaptive immune system with respect to $\alpha$-syn pathology.

Methods: We injected human $\alpha$-syn preformed fibrils (PFFs) into the striatum of immunocompromised mice (NSG) and assessed accumulation of phosphorylated $\alpha$-syn pathology, proteinase K-resistant $\alpha$-syn pathology and microgliosis in the striatum, substantia nigra and frontal cortex. We also assessed the impact of adoptive transfer of naive $\mathrm{T}$ and $\mathrm{B}$ cells into

Results: Compared to wildtype mice, NSG mice had an 8-fold increase in phosphorylated $\alpha$-syn pathology in the substantia nigra. Reconstituting the $\mathrm{T}$ cell population decreased the accumulation of phosphorylated $\alpha$-syn pathology and resulted in persistent microgliosis in the striatum when compared to non-transplanted mice.

Conclusion: Our work provides evidence that T cells play a role in the pathogenesis of experimental $\alpha$-synucleinopathy.

Keywords: Parkinson's disease, multiple system atrophy, alpha-synuclein, phosphorylated alpha-synuclein, T lymphocytes,

\section{INTRODUCTION}

The pathogenesis of Parkinson's disease (PD) and multiple system atrophy (MSA) are poorly understood, but neuroinflammation and $\alpha$-synuclein 
( $\alpha$-syn) aggregation are believed to play key roles [1-4]. Progressive spread of Lewy pathology is thought to contribute to clinical decline in PD and to be the result of cell-to-cell propagation of $\alpha$-syn aggregates [5]. Neuroinflammation, microglia activation and function is believed to be involved in the initial formation and spread of $\alpha$-syn aggregates [4, 6-10]. Studies indicate that activated microglia and elevated neuroinflammatory markers in the central nervous system are present in MSA and PD [3, 11-17]. Single nucleotide polymorphisms close to numerous immune system-related genes affect PD risk, further supporting a role for neuroinflammation in PD $[18,19]$. While the majority of studies exploring inflammation in PD have implicated changes in the innate immune system $[4,20]$, the role of the adaptive immune system in PD has been explored to a lesser extent. Notably, peripheral immune cells enter the brain during neurodegeneration [21]. T lymphocytes are altered and infiltrate the brain in PD [22-29] and it has been reported that autoreactive T lymphocytes directed against $\alpha$-syn are present in PD patients [30] decades prior to motor PD [31]. Recruitment of CD $4+\mathrm{T}$ cells to the brain occurs in models of $\alpha$-syn overexpression [32]. In PD models, T cell function has been linked to $\alpha$-syn pathobiology [33-35] and to the death of dopamine neurons $[8,36]$. Specifically, T cells respond to $\alpha$-syn variants associated with PD and then migrate into the brain where they affect the phenotype of microglia [35]. Overexpression of $\alpha$-syn induces microglia to express major histocompatibility complex II (MHC II) [37] and to present antigens to $\mathrm{CD} 4{ }^{+} \mathrm{T}$ cells $[8,36]$. These interactions between T cells, microglia, and pathogenic $\alpha$-syn are, however, not well understood. It has been difficult to interrogate the roles of the different populations of immune cells in a model of $\alpha$-synucleinopathy, as it has been done for other diseases (e.g., multiple sclerosis [38]). We addressed this gap in knowledge by triggering $\alpha$-syn pathology in immunocompromised (NOD scid gamma: NSG, lacking T, B and Natural Killer cells) mice and reconstituting select populations of immune cells. Specifically, we triggered $\alpha$-syn pathology by intrastriatal injection of human $\alpha$-syn preformed fibrils (PFFs) in control mice, NSG mice and NSG mice where T or B cell populations had been reconstituted. We assessed pathological accumulation of phosphorylated $\alpha$-syn in multiple brain regions and found that NSG mice displayed elevated pathology, while the reconstitution of T cells in NSG mice was associated with partial reduction of $\alpha$-syn neuropathology.

\section{MATERIALS AND METHODS}

\section{Study design}

The goal of our study was to define whether a compromised immune system influences the accumulation of pathological $\alpha$-syn in the brain in vivo. To this end, we assessed phosphorylated $\alpha$-syn pathology following intrastriatal injections of human $\alpha$-syn PFFs in immunocompromised and control mice. First, we established whether the PFFs injection in the striatum of immunocompromised mice resulted in altered $\alpha$-syn pathology compared to when the PFFs were injected into wildtype mice. Second, we determined the effects on neuropathology of reconstituting $\mathrm{T}$ cells in immunocompromised mice that had received intrastriatal PFFs.

\section{Animals}

We utilized 10- to 12-week-old C57BL/6J and NSG mice [immunocompromised, lacking T, B and Natural Killer (NK) cells] mice for injections, and additionally isolated $\mathrm{T}$ and $\mathrm{B}$ cells from female C57BL/6J mice (bred in our internal vivarium colony). Mice were housed at a maximum of five per cage under a $12 \mathrm{~h}$ light $/ 12 \mathrm{~h}$ dark cycle with access to food and water ad libitum. The housing of the animals and all procedures were carried out in accordance with the Guide for the Care and Use of Laboratory Animals (United States National Institutes of Health) and were approved by the Van Andel Research Institute's Institutional Animal Care and Use Committee (AUP 16-12-033). NSG mice carry two mutations on the NOD/ShiLtJ genetic background (severe combined immune deficiency (scid) and a complete null allele of the IL2 receptor common gamma chain $\left.-I L 2 \mathrm{rg}^{\text {null }}\right)$ [39]. The scid mutation renders the mice $\mathrm{B}$ and $\mathrm{T}$ cell deficient whereas the $I L 2 \mathrm{rg}^{\text {null }}$ mutation leads to a deficiency in functional NK cells $[39,40]$

\section{Purification of recombinant $\alpha$-synuclein and assembly of pre-formed fibrils}

Recombinant human $\alpha$-syn was purified similarly to this previously published protocol [40, 41]. Briefly, the protein was expressed in BL21 E.coli transformed with a plasmid expressing human $\alpha$-syn. Once expressed, cells were collected and stored at $-80^{\circ} \mathrm{C}$. For purification, cells were lysed by sonication and boiling, and centrifuged to remove cell debris. The $\alpha$-syn-containing supernatant was dialyzed overnight 
in $10 \mathrm{mM}$ Tris, $\mathrm{pH} 7.5,50 \mathrm{mM} \mathrm{NaCl}$, and $1 \mathrm{mM}$ EDTA, using SnakeSkin Dialysis Tubing MWCO 7,000 (Thermo Scientific). Chromatographic separation was performed using a Superdex 200 Column (GE Healthcare Life Sciences) and a Hi-trap Q HP anion exchange column (GE Healthcare Life Sciences). Fractions containing $\alpha$-syn were identified by SDS-PAGE and Coomassie staining, and then dialyzed overnight into PBS buffer (Life Sciences). A NanoDrop 2000 (Thermo Fisher) was used to determine the protein concentration by $\mathrm{OD}_{280}$ reading and protein was concentrated to $5 \mathrm{mg} / \mathrm{mL}$ using a Vivaspin protein concentrator spin column with a MWCO of $5 \mathrm{kDa}$ (GE Healthcare). Aliquots of $500 \mu \mathrm{L}$ were stored at $-80^{\circ} \mathrm{C}$ until use. For amyloid fibril assembly, purified recombinant $\alpha$-syn was thawed and subjected to continuous shaking at 1,000 r.p.m at $37^{\circ} \mathrm{C}$ in a Thermomixer (Eppendorf) for 7 days. The monitoring of fibril assemblies was performed by Thioflavin T (Sigma) fluorescence reading (data not shown). Fibrils were aliquoted and frozen at $-80^{\circ} \mathrm{C}$ until use.

\section{Stereotactic injections}

Prior to injection, human $\alpha$-syn PFFs were thawed and sonicated at RT in a water-bath cup-horn sonicator (Misonix XL2020, 50\% power, 120 pulses $1 \mathrm{~s}$ ON, $1 \mathrm{~s}$ OFF for $2 \mathrm{~min}$ ). Following sonication, we then prepared transmission electron microscope grids and stained the PFFs negatively with $1 \%$ uranyl acetate to control the morphology of the fibrils prior to injection. Grids were imaged using a Tecnai G2 Spirit TWIN transmission electron microscope at $120 \mathrm{kV}$ (FEI Company, Fig. 1a). Mice were anesthetized with an isoflurane/oxygen mixture and injected unilaterally with either $2 \mu \mathrm{L}$ of PFFs $(5 \mu \mathrm{g} / \mu \mathrm{L})$ or $2 \mu \mathrm{L}$ of saline as a control in the dorsal striatum [42] (coordinates from bregma: AP: $+0.2 \mathrm{~mm}$; ML: $-2.0 \mathrm{~mm}$; DV:-2.6 mm from dura) at a rate of $0.2 \mu \mathrm{L} / \mathrm{min}$ using a glass capillary attached to a $10 \mu \mathrm{L}$ Hamilton syringe. After injection, the capillary was left in place for 3 minutes before being slowly removed.

\section{Adoptive transfer}

Splenocytes obtained from wildtype mice were transferred i.p. $\left(1 \times 10^{7}\right.$ cells/mouse $)$ into NSG mice 4 weeks post PFFs injection. The optimal number of $\mathrm{T}$ and $\mathrm{B}$ cells for adoptive transfer ranges from $1 \times 10^{6}-1 \times 10^{7}$ cells/mouse [43-48]. Purification of $\mathrm{T}$ and $\mathrm{B}$ cells from total splenocytes was carried out by negative selection using Dynabeads untouched mouse $\mathrm{T}$ cell kit (the antibody mix for mouse $\mathrm{T}$ cells contains a mixture of rat monoclonal antibodies against mouse CD45R (B220), CD11b (Mac1), Ter-119, and CD16/CD32 and Dynabeads untouched CD43 B cells isolation kit (anti-mouse CD43 antibody) according to the manufacturer's instruction (Invitrogen). Successful transfer of splenocytes was confirmed by flow cytometric analysis of blood and spleen at the conclusion of the study.

\section{Euthanasia}

Mice were deeply anesthetized with sodium pentobarbital at 12 weeks post PFFs-injection. First, the spleen was rapidly collected and kept on ice and blood was collected in $0.5 \mathrm{mM}$ EDTA/ $100 \mu \mathrm{L}$ of blood. and kept at RT until flow cytometric analysis. Mice were then transcardially perfused with $0.9 \%$ saline followed by $4 \%$ paraformaldehyde in phosphate buffer. Brains were collected and post-fixed for 24 hours in $4 \%$ PFA, and then stored at $4{ }^{\circ} \mathrm{C}$ in $30 \%$ sucrose in phosphate buffer until sectioning.

\section{Flow cytometric analysis}

Immunophenotyping of isolated blood and splenocytes was performed. Blood was collected by cardiac puncture using a $26 \mathrm{G}$ needle. A minimum of $300 \mu \mathrm{L}$ was collected into microfuge tubes containing $0.5 \mathrm{mM}$ EDTA $/ 100 \mu \mathrm{L}$ of blood. Blood was lysed using $1 \times$ RBC lysis buffer (eBioscience), spun 300 $\mathrm{x} g$ for 10 mins, and the pellet was resuspended in flow buffer: PBS (minus $\mathrm{Ca}^{2+} / \mathrm{Mg}^{2+}, 2 \%$ fetal bovine serum) to bring cell number to $\sim 5 \times 10^{6}$ cells $/ \mathrm{mL}$. Staining of blood cells were performed on $50 \mu \mathrm{L}$ of blood incubated with antibodies for 30 min, RT; SuperBright 702 anti-mouse CD45.1 (clone A20, $0.5 \mu \mathrm{g}$, Invitrogen) or PE-Dazzle595 anti-mouse CD45.1 (clone A20, $0.5 \mu \mathrm{g}$, BioLegend), monoclonal anti-mouse CD45.2 APC (clone 104, $0.125 \mu \mathrm{g}$, BioLegend), FITC anti mouse CD $3 \varepsilon(1 \mu \mathrm{g}$, Clone 145-2C11, BioLegend), and PE anti-mouse CD19 (clone 6D5, $0.5 \mu \mathrm{g}$, BioLegend). For splenocyte isolation and staining, spleens were isolated from mouse and kept on ice. In cold $1 \times$ RBC lysis buffer (eBioscience), spleens were macerated with the base of a $3 \mathrm{~mL}$ syringe plunger on a $70 \mu \mathrm{m}$ cell strainer in a $10 \mathrm{~cm}$ petri dish on ice. $30 \mathrm{~mL}$ of PBS was added to stop the reaction. Cells were spun at $350 \times \mathrm{g}$ for $5 \mathrm{~min}$ at $4^{\circ} \mathrm{C}$. Pellet was resuspended in $1 \mathrm{~mL}$ of PBS for $\sim 5 \times 10^{6}$ cells $/ \mathrm{mL}$. Staining of splenocyte 
a

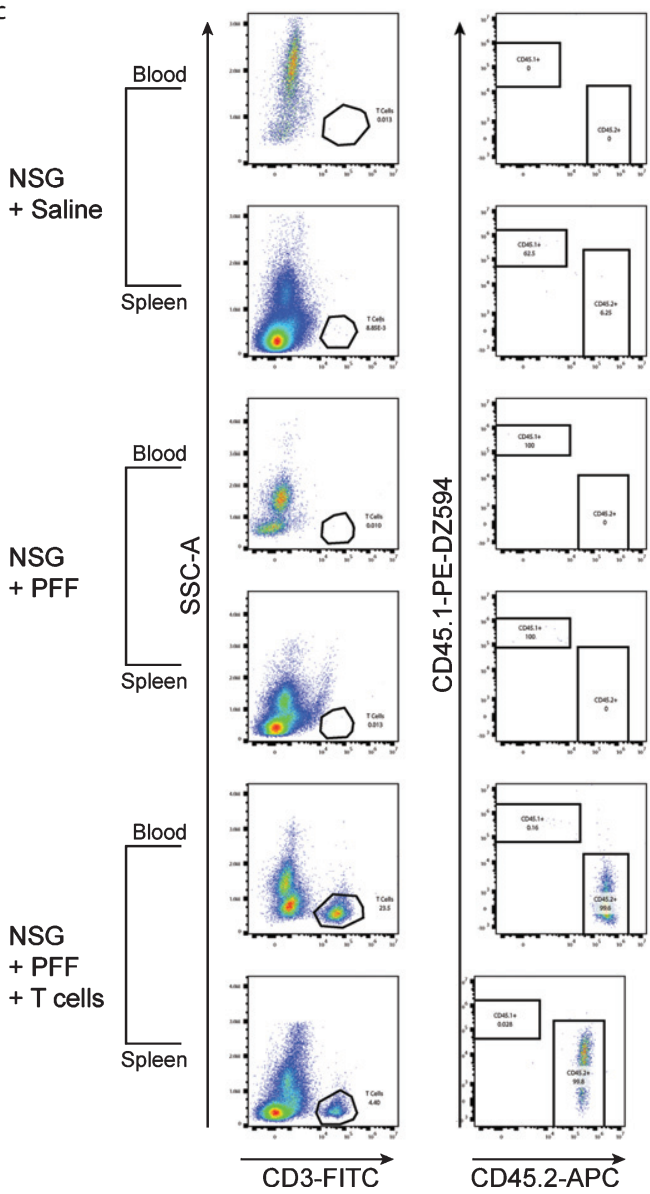

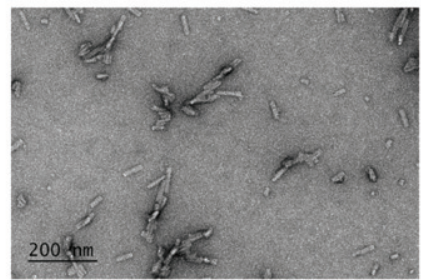

d

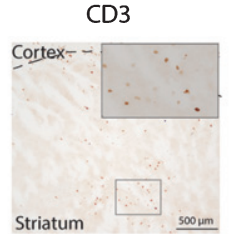

e
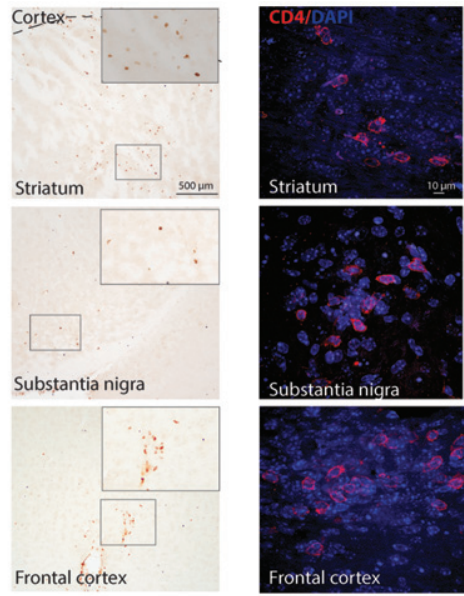

$f$

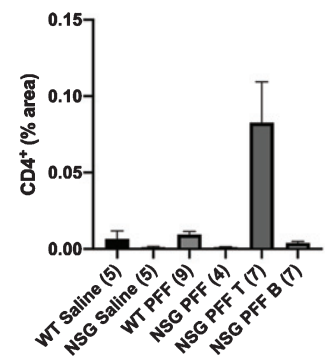

Fig. 1. T cells in the blood, spleen and brain following adoptive transfer. a) Timeline of the experiment. b) PFFs were sonicated and validated by transmission electron microscopy. c) Flow cytometric analysis. Wildtype mice contained populations of $\mathrm{T}$ and B cells that are CD45.2 positive. NSG mice did not contain T and B cell populations. Following adoptive transfer of T cells to NSG mice, CD45.2 + $\mathrm{CD}^{+} \mathrm{T}$ cells were detected. Representative plots are shown for each treatment condition. d) Representative images from the mouse striatum, substantia nigra and frontal cortex staining positive for $\mathrm{CD}^{+} \mathrm{T}$ cells in mice that received adoptive transfer of $\mathrm{T}$ cells. e) Immunofluorescent staining for $\mathrm{CD} 4{ }^{+} \mathrm{T}$ cells in the striatum, substantia nigra and frontal cortex. f) Percentage area of tissue that is positive for CD4 signal in striatum, substantia nigra and frontal cortex combined. Scale bar: $500 \mu \mathrm{m}$ and $10 \mu \mathrm{m}$. Schematic created with BioRender.com.

cells was performed on $100 \mu \mathrm{L}$ cells as described for blood. Following antibody incubation, blood and spleen cells were washed in flow buffer and spun at $300 \times \mathrm{g}$ for $10 \mathrm{~min}$. Pellets were resuspended in $300 \mu \mathrm{L}$ of flow buffer with $1 \mu \mathrm{g} / \mathrm{mL}$ DAPI. Samples were acquired on a CytoFLEX S (BeckmanCoulter).
Data analysis was performed using FlowJo v10.5.3. After gating on single live cells, T cells and B cells were identified in plots of CD3 vs SSC and CD19 vs $\mathrm{SSC}$ respectively. The mouse origin of the $\mathrm{B}$ and $\mathrm{T}$ cell susbsets was confirmed by looking at the presence of CD45.1 vs CD45.2 in each population. 


\section{Histology}

Brains were sectioned into $40 \mu \mathrm{m}$-thick free-floating coronal sections using a freezing microtome. Brain sections were stored in cryoprotectant and quenched with sodium peroxide. During the staining protocols, sections were incubated at room temperature overnight with primary antibodies directed against phosphorylated $\alpha$-syn (rabbit anti-pS129, Abcam) at 1:10000 dilution, microglia (rabbit antiIba-1, WAKO) at 1:500 dilution, and an antibody to tyrosine hydroxylase (TH, rabbit, 1:1600, EMD Millipore). To detect proteinase K resistant phosphorylated $\alpha$-syn, free-floating sections were incubated with proteinase $\mathrm{K}$ for $10 \mathrm{~min}, 10 \mu \mathrm{g} / \mathrm{mL}$ in PBS prior to primary antibody incubation. Proteinase $\mathrm{K}$ treatment was used as an antigen retrieval step for phosphorylated $\alpha$-syn staining as used in as an epitope retrieval method $[49,50]$. Sections containing the substantia nigra were stained for $\mathrm{TH}$ and mounted onto gelatin coated slides for stereological assessment of cell counts, and counter-stained with Cresyl violet for assessment of $\mathrm{Nissl}^{+}$cells. To detect $\mathrm{CD}^{+}{ }^{+}$and $\mathrm{MHC}$ II in the striatum, substantia nigra and frontal cortex of mice, we used a heat induced antigen retrieval protocol using a Universal HIER antigen retrieval reagent (Abcam). Sections were incubated with rat anti-CD3 (Abcam) at 1:100 dilution or rabbit anti MHC II at 1:500 dilution (Thermo Fisher). Sections were incubated with rabbit or rat biotinylated secondary antibodies (Vector Laboratories) and conjugated with an ABCHRP biotin/avidin complex kit (Vector Laboratories). Staining was developed with 3, 3'-diaminobenzidine then sections were mounted for imaging and analysis. Representative images of phosphorylated $\alpha$-syn pathology and microglia were acquired at $20 \mathrm{x}$ magnification using a Nikon Eclipse Ni-U microscope. List of antibodies used in the manuscript are included in Supplementary Table 1 .

\section{Immunofluorescence}

To detect $\mathrm{CD} 4{ }^{+}$cells we used heat induced antigen retrieval (as detailed above). Sections were incubated with rabbit anti-CD4 (Abcam) at 1:100 dilution. Next, sections were treated with donkey anti-rabbit Alexa 594 (1:500 dilution, Invitrogen) with DAPI (1:10000 dilution) added to the secondary solution. Sections were mounted and coverslipped using Vectashield mounting medium (Vector Laboratories) Representative images of $\mathrm{CD} 4{ }^{+}$were acquired at $20 \mathrm{x}$ magnification using a Nikon Eclipse Ni-U microscope.

\section{Image $J$ analysis of phosphorylated $\alpha$-syn pathology, MHC II and $\mathrm{CD}^{+}$ immunofluorescence}

We investigated phosphorylated $\alpha$-syn pathology in the ipsilateral hemisphere to the PFF injection and in the contralateral striatum, substantia nigra and frontal cortex of mice injected with human $\alpha$-syn PFFs by densitometry. Briefly, we acquired photomicrographs from slides at 20x magnification on three consecutive sections, three images per section, distanced by a $240 \mu \mathrm{m}$ interval. Striatal images, were captured at the level of bregma $+0.26 \mathrm{~mm}$, the images from the substantia nigra were captured from bregma $-3.08 \mathrm{~mm}$ and the frontal cortex images from bregma $+3.20 \mathrm{~mm}$. The images of phosphorylated $\alpha$-syn and MHC II stained tissue were then analyzed in ImageJ64 (Rasband WS (1997) ImageJ (modified in 2016), NIH, Bethesda, Maryland, USA). The signal for MHC II in WT saline mice was used as a background level and subtracted from all the groups. Images were converted to 8bit grayscale. We set thresholds for each image and analyzed particles in order to obtain the size of the area (A.U.) of the phosphorylated $\alpha$-synpositive regions. We determined the average grey value in each brain region and plotted each animal. For $\mathrm{CD} 4{ }^{+}$immunofluorescence, 20x images were analyzed by Image J. Images were converted to 8bit grayscale. We set a threshold for each section using the triangle setting, and then converted images to black background (of binary masks). We recorded the fraction of each area (striatum, substantia nigra and frontal cortex) that was positive and expressed it as a percentage.

\section{Assessment of numbers of microglia and their morphology}

Microglia morphology was assessed as previously described [51]. Color (RGB) images of Iba-1-stained striatum, substantia nigra and frontal cortex tissues were acquired bilaterally at 60x magnification (oil immersion 1.40 N.A.) using a Nikon Eclipse Ni$\mathrm{U}$ microscope. A total of nine images/animal were analyzed; three images from three sequential brain sections through the striatum (as described above). To assess the morphology of microglia in the samples, RGB color images were processed by a custom 
MATLAB (Mathworks) script. Cell bodies and other large regions were segmented first. Dynamic thresholds were determined for both the blue intensity and saturation channels of the image. Upper and lower bounds of the thresholds were set to match the full width at half maximum of curves fit to the histograms of each channel. If the signal met the required criteria for either the blue channel or the saturation channel thresholds, it was selected for further analysis. Segmented regions were filtered to remove small (under 2,000-pixel) areas and to remove objects that touched the borders of the image. The segmented areas were eroded to more accurately conform to cell bodies. The ratio of area:perimeter (referred to as hydraulic radius) was calculated and used as a measure for microglial activation; activated microglia are amoeboid in shape and therefore exhibit a larger index score. Microglia numbers and process length were analyzed using HALO $^{\mathrm{TM}}$ quantitative pathology software (Indica Labs).

\section{Stereological counting}

We used a computer-assisted cell quantification program (StereoInvestigator, MBF Bioscience) coupled to a Nikon Eclipse Ni-U microscope (Nikon). In each mouse (3-7 animals per group), we analyzed 5-7 sections containing substantia nigra. They were spaced by $240 \mu \mathrm{m}$ (section interval $=6$ ). Contours of the region were drawn at 10x magnification (air immersion, N.A. 0.45). Quantifications were performed at 60x (oil immersion, N.A. 1.40) using a counting frame of $100 \mu \mathrm{m} \times 100 \mu \mathrm{m}$, grid size set to $200 \times 200 \mu \mathrm{m}$, with a guard zone of $2 \mu \mathrm{m}$, and dissector height set at $12 \mu \mathrm{m}$.

\section{Statistical analysis}

The data represented in Fig. 2 includes pilot 1 data for all groups except NSG PFF B. In Pilot 2, the NSG PFF $T$ group was repeated and included 3 additional mice to determine if the same reduction in phosphorylated $\alpha$-synuclein pathology would be observed in Pilot 1. As there were no statistical differences in the NSG PFF T cell group between pilots 1 and 2, the data for this group was pooled. (see Supplementary Figure 1). In pilot 2, the experiment focused on the NSG PFF B group, to determine how the reconstitution of B cells affects phosphorylated $\alpha$-synuclein pathology. These mice were compared directly with the other groups in Pilot 2, as represented in Fig. 3 and Supplementary Figure 1.
All values are expressed as mean \pm SEM. Differences in means between the groups were analyzed using a Kruskal-Wallis test with Dunn's multiple comparisons test as posthoc (GraphPad Prism software, version 9). A $p$ value $<0.05$ was considered statistically significant.

\section{RESULTS}

\section{Decreased phosphorylated $\alpha$-syn in NSG mice reconstituted with $T$ cells}

The accumulation of phosphorylated $\alpha$-syn inclusions in wildtype and NSG mice twelve weeks after a single intrastriatal injection with recombinant human $\alpha$-syn PFFs is presented in Fig. 1 (experimental timeline in Fig. 1a). We investigated whether reconstituting the T cell population in PFFs-injected NSG mice would alter the levels of phosphorylated $\alpha$-syn in the striatum, substantia nigra or frontal cortex compared to WT and NSG mice injected with PFFs alone. The sizes of the PFFs were verified by transmission electron microscopy (Fig. 1b), which were consistent with the PFFs used in our previous studies [41]. Throughout the manuscript, we refer to NSG mice injected with human $\alpha$-syn PFFs and reconstituted with T cells as NSG PFF T and NSG mice injected with human $\alpha$-syn PFFs and reconstituted with B cells as NSG PFF B. We conducted the reconstitution of T cells in two separate experiments and the results were pooled after we determined that there was no difference in the neuropathological outcomes between the two experiments (Supplementary Figure 1).

Mice were injected with PFFs in the striatum; four weeks later, the adoptive transfer of immune cells was performed. Pathology was assessed 12 weeks post PFFs injection. Flow cytometry plots from the blood and splenocytes isolated from the reconstituted NSG mice were positive for $\mathrm{CD} 3{ }^{+} \mathrm{CD} 45.2^{+}$ $\mathrm{T}$ cells. $\mathrm{C} 57 \mathrm{Bl} / 6 \mathrm{~J}$ mice express the CD45.2 allele while NSG mice express the CD45.1 allele (representative plots in Fig. 1c), therefore CD45.2 positive cells demonstrated the successful uptake of donated $\mathrm{T}$ cells. The gating strategy is provided in Supplementary Figure 2. Supplementary Tables 2 and 3 contain individual counts of $\mathrm{T}$ cells $/ \mu \mathrm{L}$ in blood and spleen flow samples. We observed $\mathrm{CD}^{+}{ }^{+}$cells in the striatum, substantia nigra and frontal cortex in PFFs injected mice that were reconstituted with $\mathrm{T}$ cells (Fig. 1d). As CD3 is also expressed on NK cells, we confirmed the presence of $\mathrm{CD}^{+}{ }^{+} \mathrm{T}$ cells in the striatum, substantia nigra and frontal cortex by 
a

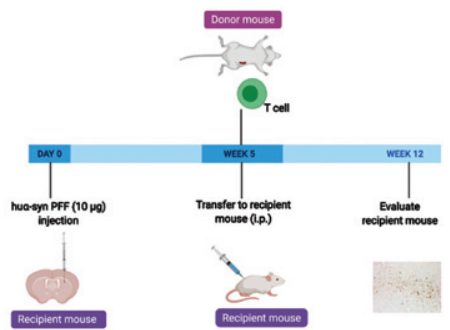

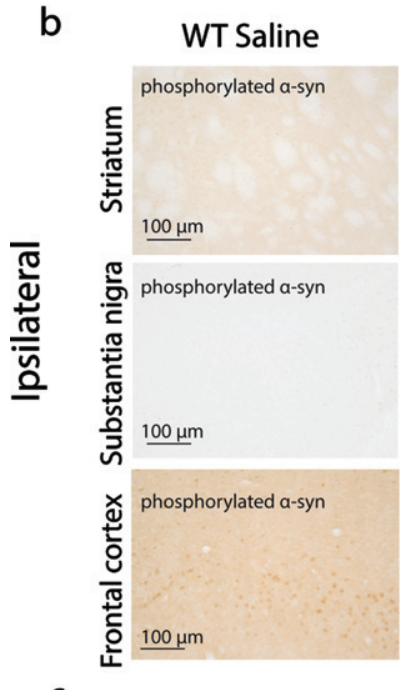

Striatum

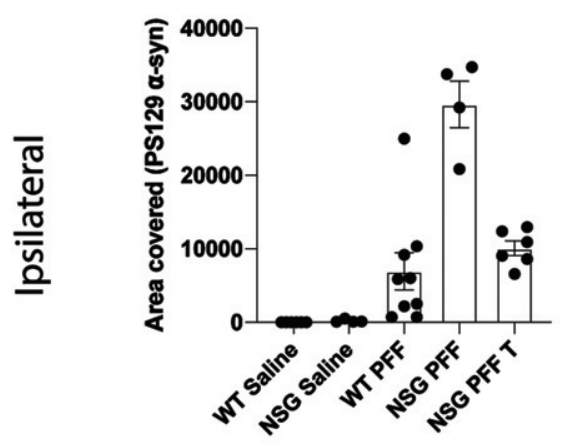

NSG Saline

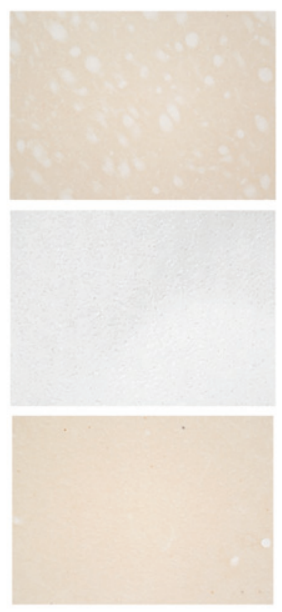

WT PFF

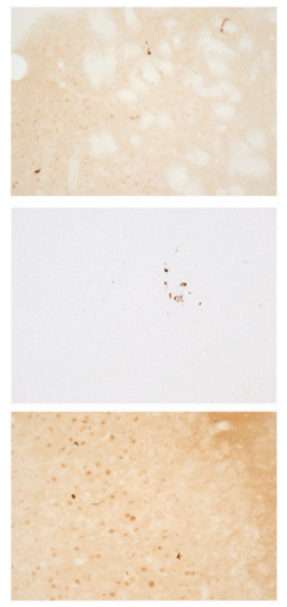

Substantia nigra

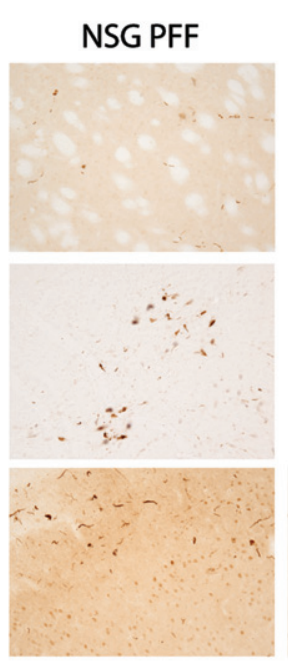

NSG PFF T

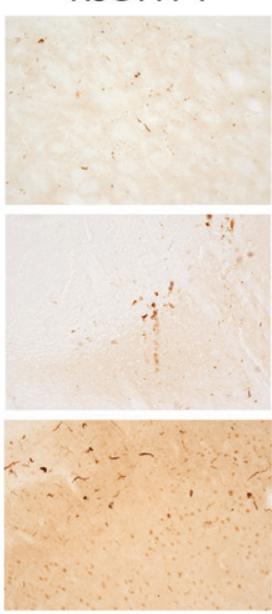

Frontal cortex
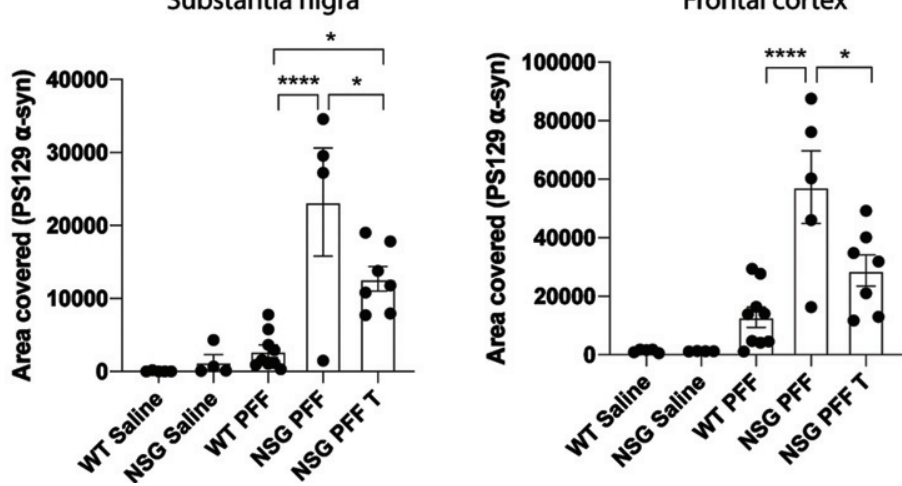

Fig. 2. Reduced phosphorylated $\alpha$-syn pathology in immunocompromised mice that received adoptive transfer of T cells. a) Timeline of experiment. b) Phosphorylated $\alpha$-syn was detected in the ipsilateral hemisphere to PFF injection in the striatum, substantia nigra and frontal cortex. The reconstitution of $\mathrm{T}$ cells was conducted in two separate experiments and the results pooled after results of the reduction in phosphorylated $\alpha$-syn were shown to be consistent between the two experiments. c) Densitometry of 5-9 mice per group to determine the area covered in phosphorylated $\alpha$-syn levels in the ipsilateral striatum, substantia nigra and frontal cortex. Wildtype Saline, $n=5$; NSG Saline $n=5$, wildtype PFF, $n=9$; NSG PFF, $n=5$; NSG PFF T $n=7$ ). d) Statistical analyses were performed by Kruskal-Wallis test $* p<0.05$, ${ }^{* * * *} p<0.001$. Scale bar: $100 \mu \mathrm{m}$. Schematic created with BioRender.com.

immunofluorescence and quantified the $\mathrm{CD}^{+}{ }^{+}$signal in the striatum, substantia nigra and frontal cortex collectively (Fig. 1e, f).

The timeline for the experiment to determine phosphorylated $\alpha$-syn pathology in NSG mice and mice reconstituted with $\mathrm{T}$ cell is presented in Fig. 2a.
Pathology in three brain regions (ipsilateral to the PFF injection), i.e., the striatum, substantia nigra and frontal association cortex (referred to as frontal cortex from hereon, see Fig. $2 b$ for representative images of pathology), were selected for quantification. In all graphs, the levels of phosphorylated $\alpha$-syn 


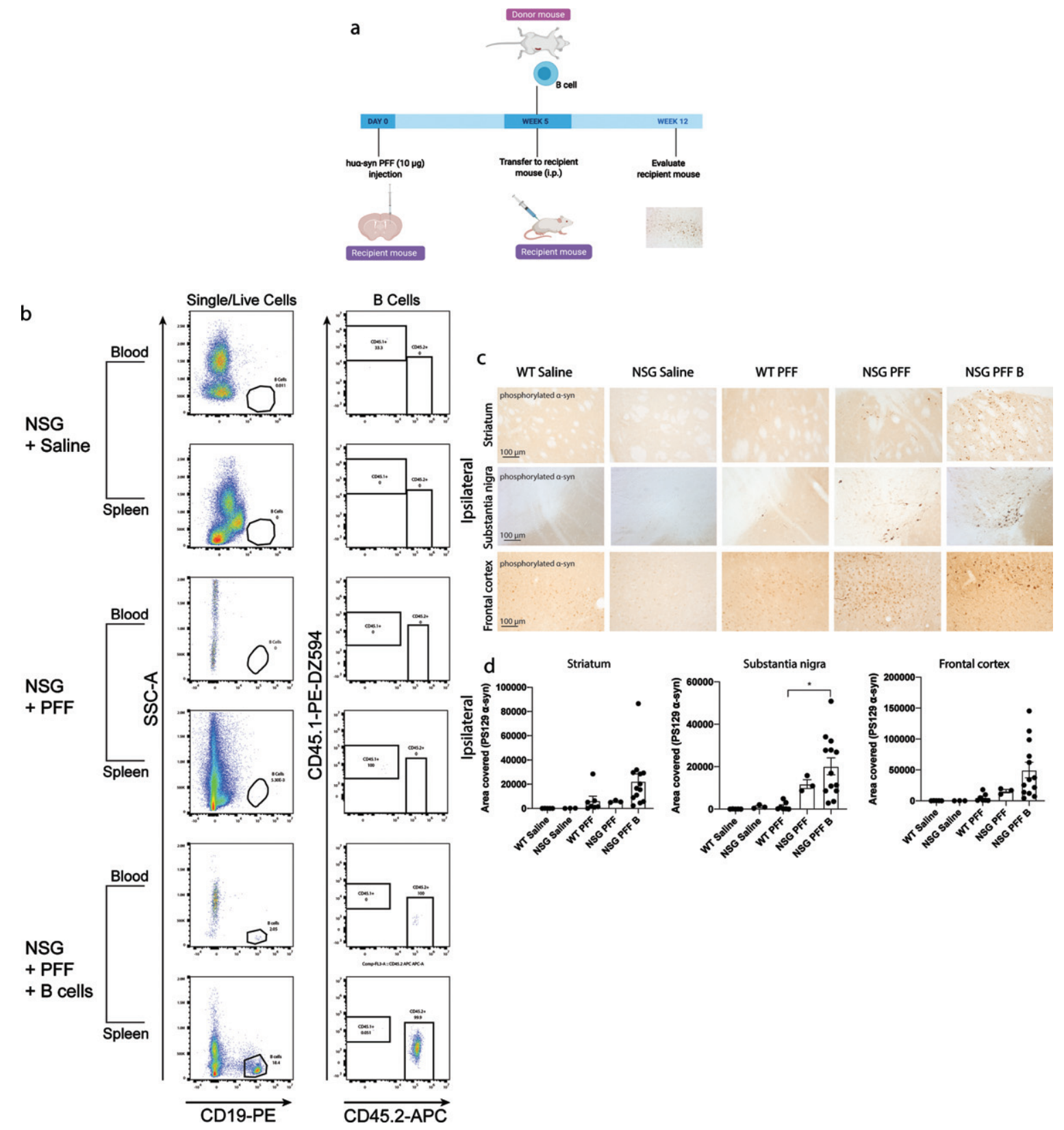

Fig. 3. Adoptive transfer of B cells alone did not alter phosphorylated $\alpha$-syn pathology in immunocompromised mice. a) Timeline of experiment. b) Flow cytometric analysis of mouse spleen and blood following adoptive transfer demonstrated that wildtype mice contain populations of T and B cells that are CD3 and CD19 positive. NSG mice do not have T and B cell populations. Following adoptive transfer of B cells, NSG mice contained CD45.2 ${ }^{+} \mathrm{CD} 19^{+} \mathrm{B}$ cells. Representative plots are shown for each treatment condition. c) Phosphorylated $\alpha$-syn was detected in the ipsilateral striatum, substantia nigra and frontal cortex. d) Densitometry of 3-9 mice per group to determine the area covered in phosphorylated $\alpha$-syn levels in the ipsilateral striatum, substantia nigra and frontal cortex. Wildtype Saline, $n=5$; NSG Saline $n=3$, wildtype PFFs, $n=3$; NSG PFFs, $n=3$; NSG PFF B $n=12$ ). The error bars represent S.E.M. Statistical analyses were performed by Kruskal-Wallis test ${ }^{*} p<0.01$. Scale bar: $100 \mu \mathrm{m}$. Schematic created with BioRender.com

is represented as the area covered by PS129 $\alpha$-syn signal. The PFFs-injected NSG mice exhibited clearly increased phosphorylated $\alpha$-syn pathology compared to PFFs-injected wildtype mice in the substantia nigra and frontal cortex and not in the striatum (Fig. 2b, c, $p<0.05$ ). Because the phosphorylated $\alpha$-syn pathology in the contralateral hemisphere (Supplementary Figure 3) was not as robust as the ipsilateral side 
within the experimental timeline (Fig. 2b, c), which would make it difficult to evaluate the changes caused by reconstituted $\mathrm{T}$ or $\mathrm{B}$ cells, we focused our analyses on the ipsilateral hemisphere. Notably, reconstituting $\mathrm{T}$ cells in NSG PFFs injected mice significantly decreased levels of phosphorylated $\alpha$-syn in the substantia nigra and frontal cortex when comparing NSG PFFs to NSG PFF T mice (Fig. 2b, c, $p<0.05$ ). The levels of phosphorylated $\alpha$-syn in the striatum following $\mathrm{T}$ cell reconstitution decreased but did not reach significance (Fig. 2c, $p>0.05$ ).

We reconstituted a different group of NSG mice with B cells to investigate the role for these cells in the propagation/accumulation of $\alpha$-syn pathology (timeline of experiment represented in Fig. 3a). The transfer of B cells was confirmed by flow cytometry (Fig. 3b, Supplementary Tables 4 and 5). Consistent with the above results, there was an increase in phosphorylated $\alpha$-syn in the ipsilateral substantia nigra in PFFs-injected NSG mice compared to PFFs-injected wildtype mice $(p<0.05$, Fig. $3 c, d)$. There was a significant increase in phosphorylated $\alpha$-syn pathology in the ipsilateral substantia nigra in the NSG PFF B compared to wildtype PFFs-injected mice (Fig. 3c, d, $p<0.05$ ). In the ipsilateral striatum, substantia nigra and frontal cortex, the levels of phosphorylated $\alpha$-syn pathology in the PFFs-injected NSG mice following the transfer of B cells did not significantly change compared to NSG PFF injected mice (Fig. 3c, d). The levels of phosphorylated $\alpha$-syn in the contralateral hemisphere did not significantly differ between the groups (Supplementary Figure 3).

We observed phosphorylated $\alpha$-syn following proteinase $\mathrm{K}$ treatment. In all groups injected with PFFs, proteinase $\mathrm{K}$ treated sections in the striatum, substantia nigra and frontal cortex were positive for phosphorylated $\alpha$-syn (Supplementary Figure 4).

\section{Microgliosis in mice reconstituted with T cells}

To understand whether microglia were involved in the reduction of phosphorylated $\alpha$-syn pathology in NSG mice reconstituted with T cells, we analyzed the morphology of microglia. We immunostained for Iba-1 to compare microglial morphology between all groups (Fig. 4a, b). We compared the morphology of Iba-1 immunoreactive microglia from the same anatomical level of the ipsilateral and contralateral striatum, substantia nigra and frontal cortex in mice from each experimental group. Specifically, we used a MATLAB script to define the ratio between the perimeter and surface area of Iba-1-immunoreactive microglia, allowing us to calculate the hydraulic radius of each cell as an index of the activation state as previously [51]. An example of the image analyzed by MATLAB is presented in Supplementary Figure 5a. The area:perimeter index (hydraulic radius) measures microglial activation as activated microglia are amoeboid in shape. Thus, these activated cells have a large area and small perimeter, increasing the index score. The hydraulic radius was significantly increased in microglia from within the ipsilateral striatum of NSG PFFs injected mice that received T cells relative to wildtype Saline, wildtype PFFs, NSG Saline, NSG PFFs, NSG PFF T, and NSG PFF B cell injected mice (Fig. 4b, $p<0.05$ ) indicating that microglia in the NSG PFF T group are activated. The hydraulic radius of microglia analyzed from the ipsilateral substantia nigra was not significantly different between the groups (Fig. $4 c, p>0.05$ ). In the ipsilateral frontal cortex, the hydraulic radius of microglia in the NSG PFF B mice was significantly reduced compared to the NSG PFF T mice (Fig. 4b, $p<0.05)$. Microglia morphology in the contralateral striatum, substantia nigra and frontal cortex did not significantly change between groups (Supplementary Figure $5 b, p>0.05$ ). We also quantified the number of microglia in the striatum, substantia nigra and frontal cortex ipsilateral to the injection (Fig. 4c). There were no significant differences in the number of microglia in either of the brain regions analyzed, nor between any of the experimental groups (Fig. 4c). We also analyzed the average process length per microglia cell as a surrogate marker of activation. We found that it did not differ between any of the brain regions analyzed, nor between any of the experimental groups (Supplementary Figure 5c, d).

Several single nucleotide polymorphisms associated with PD risk are found in and around the human leukocyte antigen (HLA) locus coding for MHC II [52]. MHC II is used by antigen presenting cells (e.g., microglia) to interact with $\mathrm{T}$ cells. We evaluated the levels of MHC II by immunohistochemistry on sections through the striatum, substantia nigra and frontal cortex (Fig. 5a, b). There was an absence of signal in the NSG Saline and NSG PFF mice however, there were no significant differences between the groups in the striatum, substantia nigra nor frontal cortex (Fig. 5b, $p>0.05$ ).

To determine whether adoptive transfer of $\mathrm{T}$ cells altered the number of surviving dopamine neurons in the substantia nigra, we performed stereological cell 


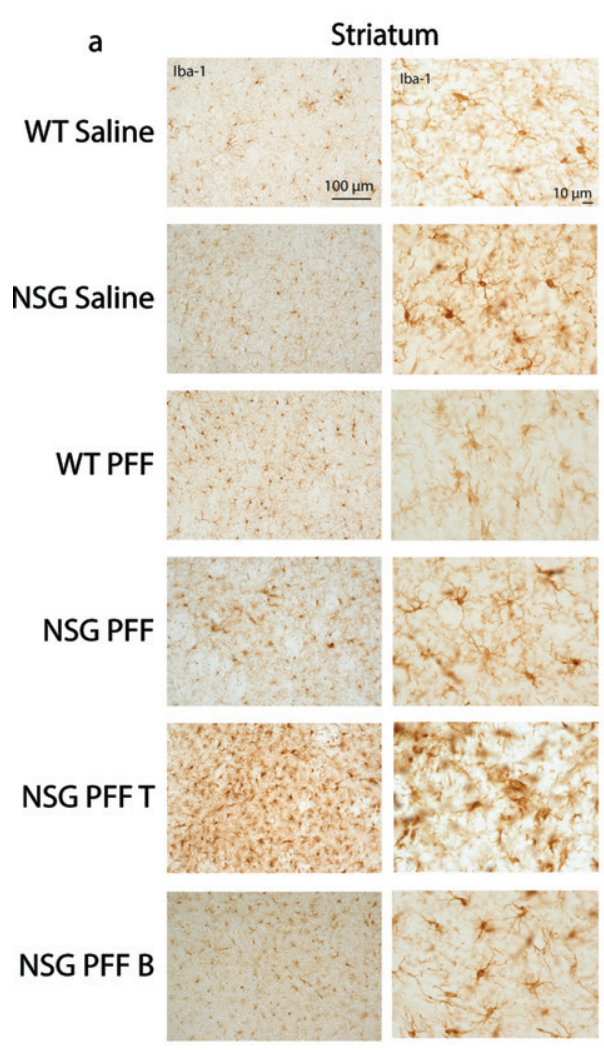

b
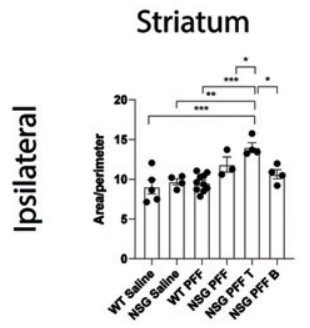

c

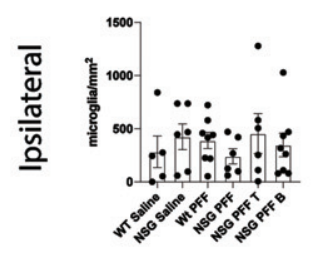

Ipsilateral

\section{Substantia nigra}
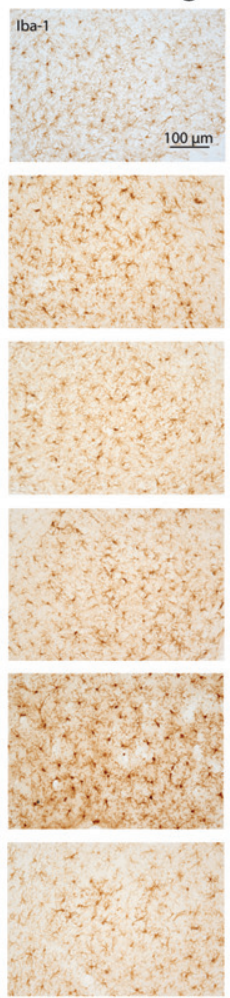

Substantia nigra
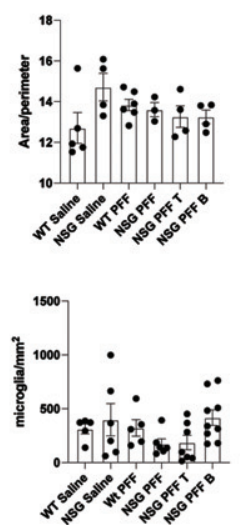

\section{Frontal cortex}

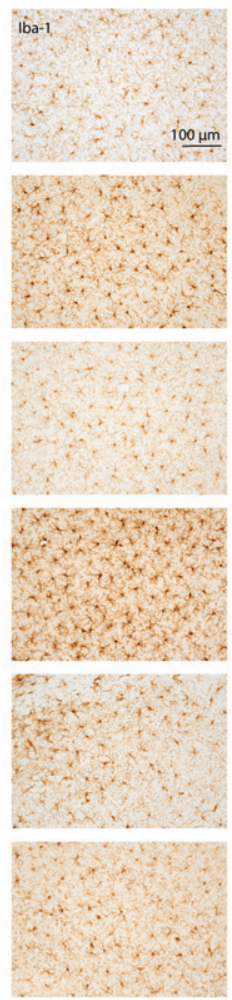

Frontal cortex
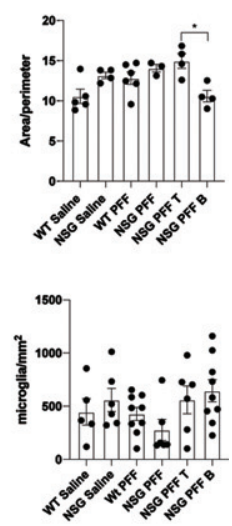

Fig. 4. Microgliosis in the brain of $\alpha$-syn PFFs injected mice. a) Representative images of Iba- 1 immunoreactive microglia were present in the ipsilateral striatum, substantia nigra and frontal cortex of saline and PFFs injected mice. High magnification examples of Iba-1 immunoreactive microglia in the striatum. b) Quantification of microglia morphology and c) microglia numbers $/ \mathrm{mm}^{2}$ in the ipsilateral hemisphere to PFF injection in the striatum, substantia nigra and frontal cortex (area/perimeter). Wildtype Saline, $n=5$; NSG Saline $n=4-6$, wildtype PFFs, $n=6-10$; NSG PFFs, $n=3-5$; NSG PFF T $n=4-7$; NSG PFF B $n=4-9$ ).

counts on TH-immunostained sections from wildtype saline, wildtype PFFs-injected and NSG saline and NSG PFFs-injected mice and from NSG mice reconstituted with $\mathrm{T}$ and $\mathrm{B}$ cells. Cell numbers were calculated as a percentage of the contralateral hemisphere. We determined that PFFs injection resulted in a decrease in TH-positive neurons (that did not reach significance, Fig. 6a), but no effect on cresyl 


\section{Ipsilateral}

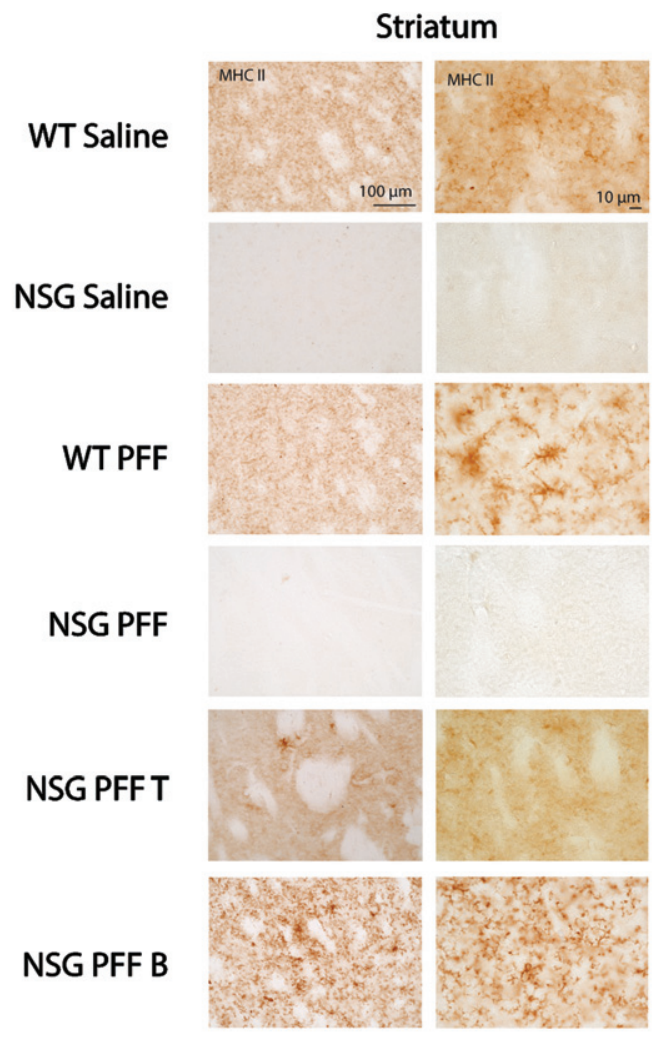

\section{Striatum}

b

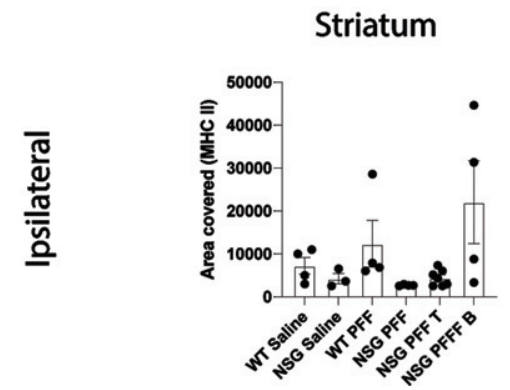

\section{Substantia nigra}

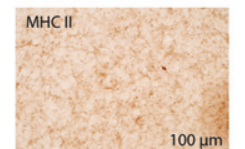

$100 \mu \mathrm{m}$
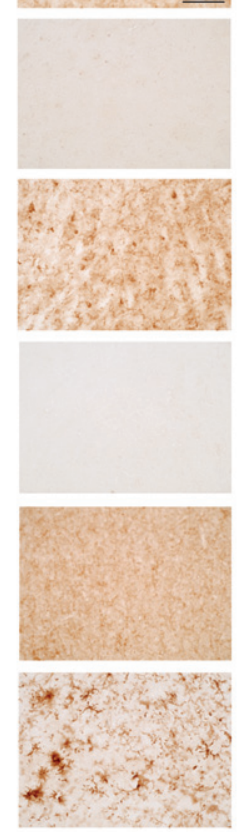

Substantia nigra

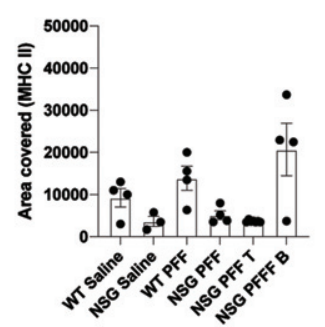

Frontal cortex
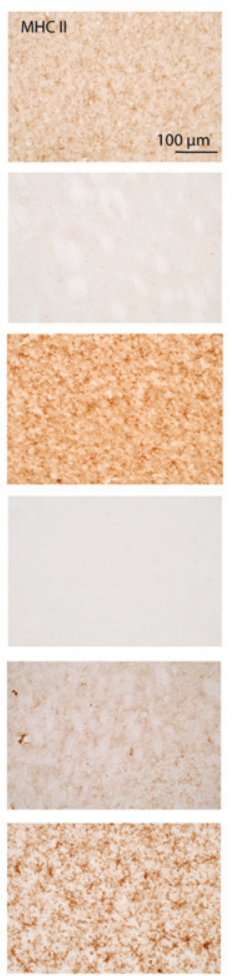

Fig. 5. MHC II in the brain of $\alpha$-syn PFFs injected mice. a) Representative images of MHC II immunoreactive cells in the ipsilateral striatum, substantia nigra and frontal cortex of saline and PFFs injected mice. High magnification examples of MHC II immunoreactive microglia in the striatum. b) Densitometry of 3-7 mice per group to determine MHCII levels in the ipsilateral striatum, substantia nigra and frontal cortex. Wildtype Saline, $n=3$; NSG Saline $n=3$, wildtype PFFs, $n=4$; NSG PFFs, $n=4$; NSG PFF T $n=7$; PFF B $n=4)$. Statistical analyses were performed by Kruskal-Wallis test. ${ }^{*} p<0.05,{ }^{* *} p<0.01,{ }^{* *} p<0.001$. Scale bar: $100 \mu \mathrm{m}$.

violet stained cells (Fig. 6b). The reconstitution of $\mathrm{T}$ or $\mathrm{B}$ cells was not significantly different from the cell loss observed in the NSG PFFs-injected mice (Fig. 6b, $p>0.05$ ). Representative TH stained substantia nigral tissue from the groups reflect the number of TH-positive neurons in mice that received the PFF injection (Fig. 6c).

\section{DISCUSSION}

\section{T cells infiltrate the brain}

We explored the role of $\mathrm{T}$ cells in the accumulation of $\alpha$-syn following intracerebral inoculation with $\alpha$ syn fibrils in immunocompromised mice (NSG) that 


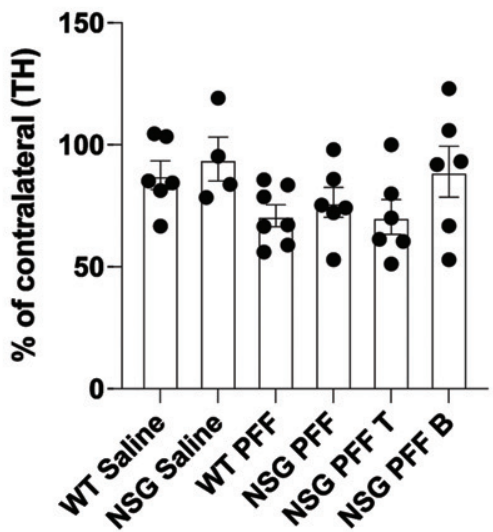

C

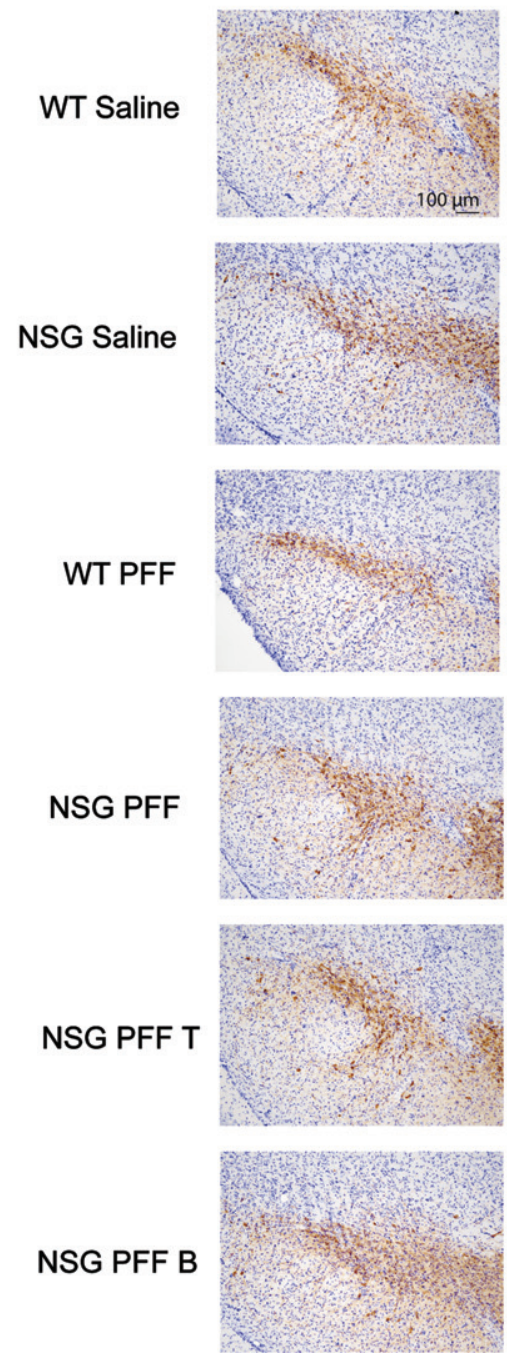

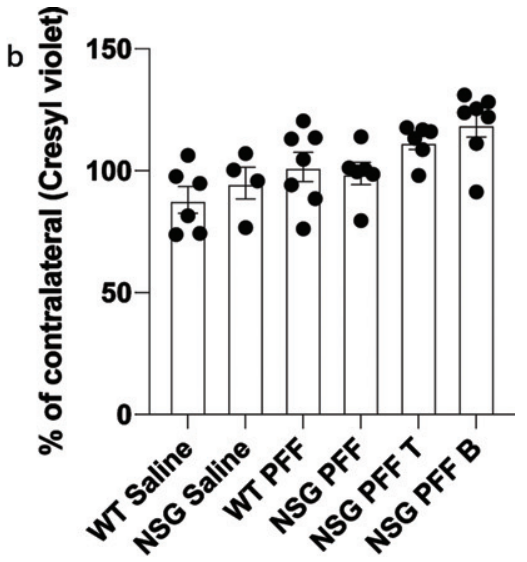
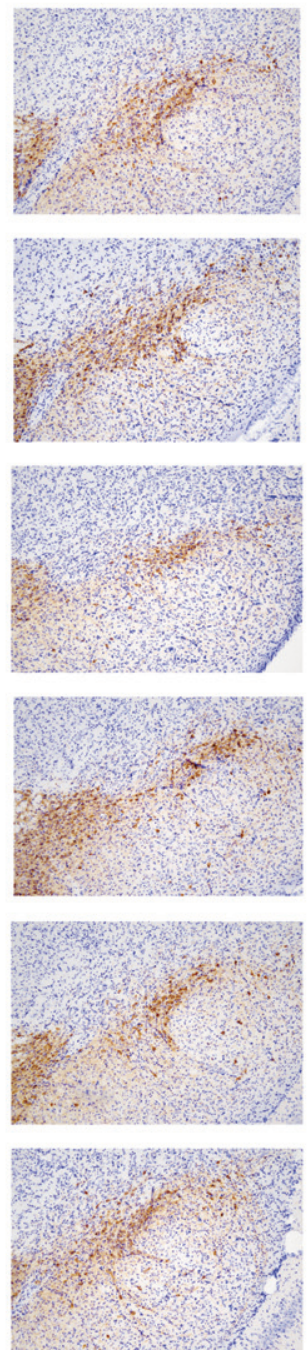

Fig. 6. Stereological counts of saline and PFFs injected wildtype and NSG mice. a) Tyrosine Hydroxylase (TH) positive cells as percentage of the contralateral hemisphere. b) Cresyl violet stained cells as percentage of the contralateral hemisphere. c) Nigral sections stained with TH and cresyl violet. Wildtype Saline, $n=6$; NSG Saline $n=4$, wildtype PFFs, $n=7$; NSG PFFs, $n=6$; NSG PFF T $n=6$; PFF B $n=7$ ). The error bars represent S.E.M. Statistical analyses were performed by Kruskal-Wallis test. 
lack B, T and NK cells [39]. We injected NSG and wildtype mice with human $\alpha$-syn fibrils into the striatum. The NSG mice developed greater accumulation of phosphorylated $\alpha$-syn in the striatum, substantia nigra and frontal cortex. To determine whether the absence of T lymphocytes was driving this elevation in phosphorylated $\alpha$-syn inclusions, we reconstituted NSG mice with $T$ cells via adoptive transfer four weeks after intrastriatal injections of $\alpha$-syn PFFs. Notably, the transfer of T cells resulted in a significant decrease in phosphorylated $\alpha$-syn immunostaining in the substantia nigra and frontal cortex, but not in the striatum. Our data imply that a critical number of $\mathrm{T}$ cells are required to affect $\alpha$-syn pathology in vivo, as significantly more $\mathrm{T}$ cells were found in the brain of NSG PFF T than WT PFFs injected mice. Having a critical number of $T$ cells to affect pathology is reflected in the number of T cells/ $\mu \mathrm{L}$ in the blood and spleen comparing WT PFF and NSG PFF T groups, as reconstituted NSG mice had a larger T cell compartment in blood than WT PFF injected mice (Supplementary Tables 2 and 3). These infiltrating $\mathrm{T}$ cells could mediate the decrease in phosphorylated $\alpha$ syn pathology in the substantia nigra. The presence of infiltrating $\mathrm{CD} 4{ }^{+} \mathrm{T}$ cells in the striatum, substantia nigra and frontal cortex following adoptive transfer, are consistent with previous work showing infiltration of $\mathrm{T}$ cells in PD brains and in a neurotoxin model of nigral neurodegeneration [22] as well as complement several reports associating altered $T$ cell function with PD and MSA [24-29, 53]. Overall, our findings of $\mathrm{CD} 4{ }^{+} \mathrm{T}$ cells are in agreement with a growing body of evidence that $\mathrm{T}$ cells invade the central nervous system in neurodegenerative conditions $[32,54,55]$.

\section{Immune cells can alter pathology and neurodegeneration}

Immune cells can modulate neuroinflammation and neurodegeneration in PD mouse models [56]. Overexpression of human $\alpha$-syn in the substantia nigra of immune competent mice results in microglial activation, MHC II activation, $\mathrm{T}$ cell and monocyte entry into the brain and consequently, loss of substantia nigra neurons $[36,57,58]$. The role of immune cells in human $\alpha$-syn transgenic mice was tested by crossing mice that lack mature $\mathrm{T}$ and $\mathrm{B}$ cells (Rag 2-/-), with $\alpha$-syn transgenic mice. The investigators observed decreased levels of $\alpha$-syn in the substantia nigra compared to the same human $\alpha$-syn transgenic mice maintained on a wild type background [59]. The levels of $\alpha$-syn aggregates in the striatum and substantia nigra (with and without proteinase $\mathrm{K}$ treatment) in wild type mice on the Rag2-/- background compared to wild type mice on the Rag $2+$ / + background show a decrease in aggregates. Therefore, mice that have intact lymphocytes, have more aggregates [59]. Our results show that following the replacement of $\mathrm{T}$ lymphocytes there is a reduction of phosphorylated $\alpha$-syn in the substantia nigra and frontal cortex following PFFs injection in the striatum. There are differences in the experimental paradigms that need to be considered between Sommer et al. [59] and our results. First, we used an antibody directed to phosphorylated $\alpha$-syn in our study, detecting a presumed pathogenic, aggregationprone or aggregated $\alpha$-syn species, while this latter study employed an antibody directed to human $\alpha$-syn (generated by the transgene) that also detects soluble $\alpha$-syn species. Second, it is known that mouse $\alpha$ syn fibrils injected into a mouse are more effective than human $\alpha$-syn fibrils in seeding further aggregation [60].

Other studies have suggested that B cells might also be involved in regulating PD-like pathology. To investigate the role for B cells in the propagation of $\alpha$ syn pathology, we injected a separate group of mice with B cells isolated from wildtype mice. Orr and coworkers [61] previously described IgG on nigral neurons and Lewy bodies in PD, indicative of the existence of a humoral B cell response in PD. However, we did not observe an effect of adoptive transfer of B cells alone on phosphorylated $\alpha$-syn pathology. The absence of a humoral response in our paradigm, in the case of NSG PFF T mice, suggests that $T$ cells only partially protect by reducing phosphorylated $\alpha$-syn pathology and not completely mitigating its presence. As B cells are involved in the regulation of $\mathrm{T}$ cell function, this suggests that $\mathrm{B}$ cells alone cannot modulate $\alpha$-syn accumulation, and that $T$ cells and $\mathrm{B}$ cells might need to work in concert to affect $\alpha$-syn pathology.

We also investigated whether the decrease in pathology observed following adoptive transfer of $\mathrm{T}$ cells could be due to $\mathrm{T}$ cells killing neurons that exhibit phosphorylated $\alpha$-syn, leading to an apparent reduction of phosphorylated $\alpha$-syn staining. This idea would be consistent with an earlier study showing that mice lacking $\mathrm{CD} 4{ }^{+} \mathrm{T}$ cells are relatively resistant to MPTP-induced degeneration of substantia nigra dopamine neurons [22]. However, our stereological counts of nigral $\mathrm{TH}$-immunoreactive neurons revealed similar reductions following intrastriatal injection of $\alpha$-syn PFFs in mice lacking T cells as 
those having their $\mathrm{T}$ cell population reconstituted (Fig. 6a). Thus, our data do not support the idea that $\mathrm{T}$ cells caused a reduction of $\alpha$-syn pathology by contributing to the death of neurons containing $\alpha$-syn aggregates.

\section{Microglia activation and function alter $\alpha$-syn pathology}

It is also possible that T cells do not reduce $\alpha$ syn pathology through a direct action but rely on other cells. Thus, the significant decrease in phosphorylated $\alpha$-syn following $\mathrm{T}$ cell reconstitution could be explained by $\mathrm{T}$ cells activating microglia, which then remove phosphorylated $\alpha$-syn. It is known that T cells invading the brain can activate microglia [54, $55,62]$. Indeed, we found that microglia morphology was significantly altered in the striatum of mice that received adoptive transfer of $\mathrm{T}$ cells following intrastriatal injection of $\alpha$-syn PFFs. Microglia have distinct region-dependent, molecular and morphological profiles [63-65] and this could explain why striatal microglia were more activated in the striatum than the substantia nigra and frontal cortex, despite these latter regions also forming $\alpha$-syn aggregates.

Microglial MHC II expression increases upon activation [66]. In NSG PFF mice that received an adoptive transfer of T cells, the MHC II signal was low. This suggests that microglia were never activated by the transferred $\mathrm{T}$ cells. Alternatively, microglia in the NSG PFF T mice initially upregulated MHCII in response to the PFFs injection, but with the processing of the antigen, the signal is absent at the time of investigation. Recently, it was reported that rats genetically modified to reduce MHC II expression in conjunction with $\alpha$-syn overexpression and PFF injection had widespread neuropathology throughout the brain compared to rats with normal levels of MHC II [9]. This absence of sustained MHC II upregulation in response to $\alpha$-syn PFFs contrasts to recently reported findings in a model involving viral overexpression of $\alpha$-syn in rats [37]. In this model, $\mathrm{T}$ cells and microglia worked synergistically to contribute to nigral dopamine neuron loss [37]. T cells can stimulate microglia through the release of Interferon (IFN) $-\gamma$ and are found to be necessary for the upregulation of MHC II in microglia [54]. Other possible reasons why $\alpha$-syn PFF injections do not lead to robust, long-term, upregulation of MHC II, in contrast to the viral $\alpha$ syn overexpression model [36, 37, 67], could be two-fold: the adeno-associated viral vector itself contributes to the inflammatory response [68] or the $\alpha$-syn species generated by the recombinant adenoassociated virus (as compared to PFFs) do not efficiently generate stable, seeding assemblies but rather overexpression of soluble $\alpha$-syn instead [69]. Thus, the $\alpha$-syn aggregates that are generated in models using recombinant adeno-associated virus and PFFs can stimulate the immune system differently. In our paradigm, the phosphorylated $\alpha$-syn pathology is derived from endogenous mouse $\alpha$-syn, as earlier work has shown that PFFs cannot seed aggregates in $\alpha$-syn null mice [70]. By contrast, when overexpressing human $\alpha$-syn by viral vectors, it is the vector-derived human $\alpha$-syn that accumulates. Taken together, our results suggest that PFFs activate microglia in select brain regions, and that the activated microglia interact with infiltrating T cells [54, 71] (Fig. 7). As a result, we propose that the activated microglia phagocytose extracellular $\alpha$-syn that has been released by neurons [72]. Because T cells can release IFN- $\gamma$, they can trigger microglia activation and increase phagocytosis, leading to reduced $\alpha$-syn pathology.

\section{$T$ cells and $\alpha$-syn vaccination}

T cells can recognize $\alpha$-syn peptides, and such $\alpha$ syn-specific $\mathrm{T}$ cells are found in the circulation in prodromal PD [31]. T cells could limit the development of pathology early in disease [31]. Vaccination therapies aimed at activating $\mathrm{T}$ cells that target $\alpha$ syn have been explored in multiple models [73-76]. Immunization with $\alpha$-syn in combination with a heatshock protein resulted in peripheral $\mathrm{T}$ cell activation and suppression of microglial activation in an acute MPTP model of PD [73]. Modulating the activation of regulatory $\mathrm{T}$ cells and microglia results in protection of dopaminergic neurons [75]. Finally, in mouse models of MSA, antibodies that target oligomeric $\alpha$-syn [74] as well as the use of an active $\alpha$-syn immunization approach [76] reduce accumulation of pathogenic $\alpha$-syn, neurodegeneration and modulate microglial activation [74, 76]. Overall, the different vaccination strategies lead to altered microglial activation and reduced neuronal cell death [77]. In this context, specific $\mathrm{T}$ cell populations appear to play a positive role. In the future, the transfer of T cells engineered to recognize specific forms of $\alpha$-syn might be employed to reduce $\alpha$-syn pathology and slow progression of symptoms in synucleinopathies. 


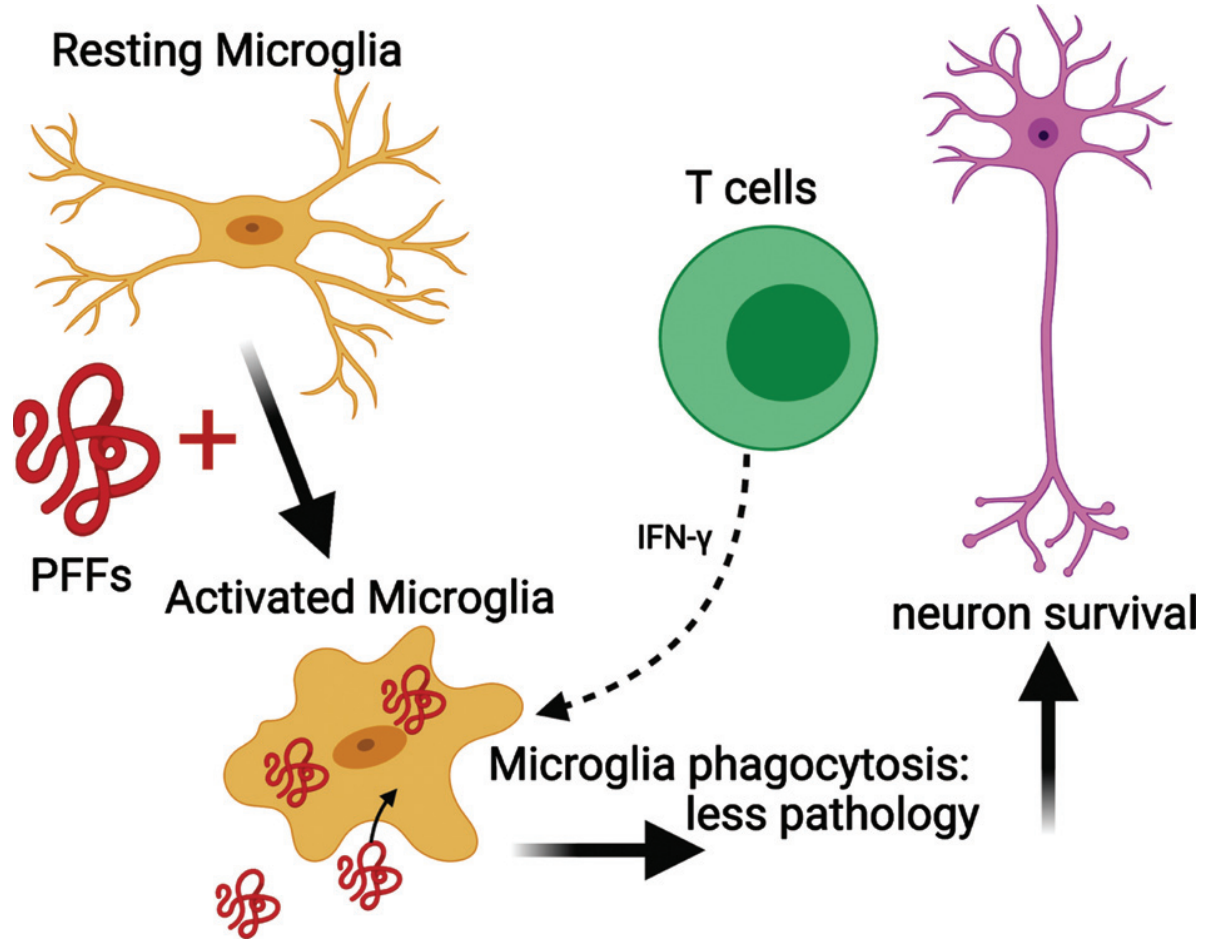

Fig. 7. Mechanism for the reduced phosphorylated $\alpha$-syn pathology in immunocompromised mice that received adoptive transfer of T cells. PFFs activate resting microglia to become active and phagocytose PFFs. The presence of $T$ cells releasing IFN- $\gamma$ helps to further activate microglia and enhance phagocytosis. This results in less pathology and neuronal survival. Schematic created with BioRender.com.

\section{The role of NK cells}

Our study did not address the influence of NK cells on the accumulation of phosphorylated $\alpha$-syn inclusions. NK cells are one of the first lines of defense of the innate immune system [78], responding rapidly to a variety of insults with cytolytic activity and cytokine secretion [79]. They are implicated in autoimmune diseases and can interact with microglia [79]. The levels of inhibitory receptors on NK cells are significantly lowered in the peripheral circulation of PD patients, rendering the NK cells more prone to activation [80]. Systemic depletion of NK cells exacerbates $\alpha$-syn pathology in A53T human $\alpha$-syn transgenic mice subjected to intrastriatal injections of human $\alpha$-syn PFFs [81]. The NSG mice we used in our study have NK deficiencies. The mutation in the interleukin-2 receptor common gamma chain leads to interrupted signaling for Interleukin-15, and a resultant complete lack of NK cells [82]. As phosphorylated $\alpha$-syn was increased in multiple brain regions in NSG mice when compared to wildtype mice (Fig. 2), the absence of NK cells could have contributed to greater $\alpha$-syn pathology, explaining why the $\mathrm{T}$ cell reconstitution only partially reduces the protein aggregate pathology. Further studies where NK cells and T cells are reconstituted alone or in combination are needed to clarify their respective roles in this paradigm.

\section{CONCLUSION}

Compared to wildtype mice injected with PFFs into the striatum, NSG immunocompromised mice injected with PFFs exhibited increased levels of phosphorylated $\alpha$-syn in the substantia nigra. The accumulation of phosphorylated $\alpha$-syn was reduced when we used adoptive transfer to reconstitute the $\mathrm{T}$ cell population in the immunocompromised mice. We observed signs of elevated microglia activation in the striatum in mice that received the $\mathrm{T}$ cell adoptive transfer. Taken together, our study provides direct in vivo evidence that $\mathrm{T}$ cells modulate accumulation of phosphorylated $\alpha$-syn and supports an important role for the immune system in PD pathogenesis.

\section{ACKNOWLEDGMENTS}

We thank Dr. Corinne Esquibel from the Optical Imaging core for developing the MATLAB algorithm 
for microglia morphology analysis, Emily Wolfrum from the Bioinformatics and Biostatistics for assistance with the statistical analysis and the staff of the Vivarium of Van Andel Research Institute for animal care. We acknowledge the Van Andel Institute and the many individuals and corporations that supported financially the neurodegenerative research at Van Andel Research Institute. S.G. was supported by the Peter C. and Emajean Cook Foundation and the Farmer Family Foundation. Research reported in this publication was supported by the National Institute On Deafness And Other Communication Disorders of the National Institutes of Health under Award Numbers R01DC016519 (P.B.) and the National Institute of Neurological Disorders and Stroke of the National Institutes of Health under Award Numbers R21NS106078-01A1 (P.B.). The content is solely the responsibility of the authors and does not necessarily represent the official views of the National Institutes of Health. We would like to acknowledge iPark and the Farmer Family Foundation for funding a portion of this work.

This work was supported by the Farmer Family Foundation and S.G. was supported by the Peter C. and Emajean Cook Foundation.

\section{CONFLICT OF INTEREST}

PB has received commercial support as a consultant from Axial Biotherapeutics, Calico, CuraSen, Fujifilm-Cellular Dynamics International, Idorsia, IOS Press Partners, LifeSci Capital LLC, Lundbeck A/S and Living Cell Technologies LTD. He has received commercial support for grants/research from Lundbeck A/S and Roche. He has ownership interests in Acousort $\mathrm{AB}$ and Axial Biotherapeutics and is on the steering committee of the NILO-PD trial. The authors declare no additional competing financial interests.

\section{SUPPLEMENTARY MATERIAL}

The supplementary material is available in the electronic version of this article: https://dx.doi.org/ 10.3233/JPD-202351.

\section{REFERENCES}

[1] Hirsch EC, Vyas S, Hunot S (2012) Neuroinflammation in Parkinson's disease. Parkinsonism Relat Disord 18, S210S212.
[2] Wakabayashi K, Yoshimoto M, Tsuji S, Takahashi H (1998) $\alpha$-Synuclein immunoreactivity in glial cytoplasmic inclusions in multiple system atrophy. Neurosci Lett $\mathbf{2 4 9}$, 180-182.

[3] Rydbirk R, Elfving B, Andersen MD, Langbøl MA, Folke J, Winge K, Pakkenberg B, Brudek T, Aznar S (2017) Cytokine profiling in the prefrontal cortex of Parkinson's Disease and Multiple System Atrophy patients. Neurobiol Dis 106, 269-278.

[4] Tan EK, Chao YX, West A, Chan LL, Poewe W, Jankovic J (2020) Parkinson disease and the immune system - associations, mechanisms and therapeutics. Nat Rev Neurol 16, 303-318.

[5] Steiner JA, Quansah E, Brundin P (2018) The concept of alpha-synuclein as a prion-like protein: Ten years after. Cell Tissue Res 373, 161-173.

[6] Zhang W, Wang T, Pei Z, Miller DS, Wu X, Block ML, Wilson B, Zhang W, Zhou Y, Hong J-S, Zhang J (2005) Aggregated $\alpha$-synuclein activates microglia: A process leading to disease progression in Parkinson's disease. FASEB J 19, 533-542.

[7] Lee H-J, Bae E-J, Lee S-J (2014) Extracellular $\alpha$ synuclein-a novel and crucial factor in Lewy body diseases. Nat Rev Neurol 10, 92-98.

[8] Kim C, Ho D, Suk J, You S, Michael S, Kang J, Joong Lee S, Masliah E, Hwang D, Lee H-J, Lee S (2013) Neuronreleased oligomeric $\alpha$-synuclein is an endogenous agonist of TLR2 for paracrine activation of microglia. Nat Commun 4, 1562 .

[9] Jimenez-Ferrer I, Bäckström F, Dueñas-Rey A, Jewett M, Boza-Serrano A, Luk KC, Deierborg T, Swanberg M (2020) The MHC class II transactivator modulates seeded alphasynuclein pathology and dopaminergic neurodegeneration in an in vivo rat model of Parkinson's disease. Brain Behav and Immun 91, 369-382.

[10] Kim YE, Lai TT, Kim YJ, Jeon B (2020) Preferential microglial activation associated with pathological alpha synuclein transmission. J Clin Neurosci 81, 469-476.

[11] Gerhard A, Pavese N, Hotton G, Turkheimer F, Es M, Hammers A, Eggert K, Oertel W, Banati RB, Brooks DJ (2006) In vivo imaging of microglial activation with $[11 \mathrm{C}](\mathrm{R})$ PK11195 PET in idiopathic Parkinson's disease. Neurobiol Dis 21, 404-412.

[12] Mogi M, Harada M, Riederer P, Narabayashi H, Fujita K, Nagatsu T (1994) Tumor necrosis factor-alpha (TNF-alpha) increases both in the brain and in the cerebrospinal fluid from parkinsonian patients. Neurosci Lett 165, 208-210.

[13] Mogi M, Harada M, Narabayashi H, Inagaki H, Minami M, Nagatsu T (1996) Interleukin (IL)-1 beta, IL-2, IL-4, IL-6 and transforming growth factor-alpha levels are elevated in ventricular cerebrospinal fluid in juvenile parkinsonism and Parkinson's disease. Neurosci Lett 211, 13-16.

[14] Brodacki B, Staszewski J, Toczyłowska B, Kozłowska E, Drela N, Chalimoniuk M, Stępien A (2008) Serum interleukin (IL-2, IL-10, IL-6, IL-4), TNF $\alpha$, and INF $\gamma$ concentrations are elevated in patients with atypical and idiopathic parkinsonism. Neurosci Lett 441, 158-162.

[15] Compta Y, Dias SP, Giraldo DM, Pérez-Soriano A, Muñoz E, Saura J, Fernández M, Bravo P, Cámara A, PulidoSalgado M, Painous C, Ríos J, Marti M-J, consortium C (2019) Cerebrospinal fluid cytokines in multiple system atrophy: A cross-sectional Catalan MSA registry study. Parkinsonism Relat Disord 65, 3-12.

[16] Yamasaki R, Yamaguchi H, Matsushita T, Fujii T, Hiwatashi A, Kira J-I (2017) Early strong intrathecal inflammation in 
cerebellar type multiple system atrophy by cerebrospinal fluid cytokine/chemokine profiles: A case control study. $J$ Neuroinflammation 14, 10-89.

[17] Li F, Ayaki T, Maki T, Sawamoto N, Takahashi R (2018) NLRP3 inflammasome-related proteins are upregulated in the putamen of patients with multiple system atrophy. $J$ Neuropathol Exp Neurol 77, 1055-1065.

[18] Hamza TH, Zabetian CP, Tenesa A, Laederach A, Montimurro J, Yearout D, Kay DM, Doheny KF, Paschall J, Pugh E, Kusel VI, Collura R, Roberts J, Griffith A, Samii A, Scott WK, Nutt J, Factor SA, Payami H (2010) Common genetic variation in the HLA region is associated with late-onset sporadic Parkinson's disease. Nat Genet 42, 781-785.

[19] Blauwendraat C, Nalls MA, Singleton AB (2020) The genetic architecture of Parkinson's disease. Lancet Neurol 19, 170-178.

[20] Ransohoff RM (2016) How neuroinflammation contributes to neurodegeneration. Science 353, 777-783.

[21] Schwartz M, Baruch K (2014) The resolution of neuroinflammation in neurodegeneration: Leukocyte recruitment via the choroid plexus. EMBO J 33, 7-22.

[22] Brochard V, Combadière B, Prigent A, Laouar Y, Perrin A, Beray-Berthat V, Bonduelle O, Alvarez-Fischer D, Callebert J, Launay J-M, Duyckaerts C, Flavell RA, Hirsch EC, Hunot S (2009) Infiltration of CD4+lymphocytes into the brain contributes to neurodegeneration in a mouse model of Parkinson disease. J Clin Invest 119, 182-192.

[23] Hickey WF (2001) Basic principles of immunological surveillance of the normal central nervous system. Glia 36, 118-124.

[24] Baba Y, Kuroiwa A, Uitti RJ, Wszolek ZK, Yamada T (2005) Alterations of T-lymphocyte populations in Parkinson disease. Parkinsonism Relat Disord 11, 493-498.

[25] Öztuna D, Asagi M, Itoyama Y, Iwasaki Y (2001) Increase in peripheral CD4 bright+CD8 dull+T cells in Parkinson disease. Arch Neurol 58, 1580-1583.

[26] Bas J (2001) Lymphocyte populations in Parkinson's disease and in rat models of parkinsonism. $J$ Neuroimmunol 113, 146-152.

[27] Saunders JAH, Estes KA, Kosloski LM, Allen HE, Dempsey KM, Torres-Russotto DR, Meza JL, Santamaria PM, Bertoni JM, Murman DL, Ali HH, Standaert DG, Mosley RL, Gendelman HE (2012) CD4+regulatory and effector/memory $\mathrm{T}$ cell subsets profile motor dysfunction in Parkinson's disease. J Neuroimmune Pharmacol 7, 927-938.

[28] Stevens CH, Rowe D, Morel-Kopp M-C, Orr C, Russell T, Ranola M, Ward C, Halliday GM (2012) Reduced T helper and B lymphocytes in Parkinson's disease. J Neuroimmunology 252, 95-99.

[29] Chiba S, Matsumoto H, Saitoh M, Kasahara M, Matsuya M, Kashiwagi M (1995) A correlation study between serum adenosine deaminase activities and peripheral lymphocyte subsets in Parkinson's disease. J Neurol Sci 132, 170-173.

[30] Sulzer D, Alcalay RN, Garretti F, Cote L, Kanter E, AginLiebes J, Liong C, McMurtrey C, Hildebrand WH, Mao X, Dawson VL, Dawson TM, Oseroff C, Pham J, Sidney J, Dillon MB, Carpenter C, Weiskopf D, Phillips E, Mallal S, Peters B, Frazier A, Arlehamn CSL, Sette A (2017) T cells from patients with Parkinson's disease recognize $\alpha$ synuclein peptides. Nature 546, 656.

[31] Arlehamn CSL, Dhanwani R, Pham J, Kuan R, Frazier A, Dutra JR, Phillips E, Mallal S, Roederer M, Marder KS, Amara AW, Standaert DG, Goldman JG, Litvan I, Peters B, Sulzer D, Sette A (2020) $\alpha$-Synuclein-specific T cell reactivity is associated with preclinical and early Parkinson's disease. Nat Commun 11, 1875.

[32] Iba M, Kim C, Sallin M, Kwon S, Verma A, Overk C, Rissman RA, Sen R, Sen JM, Masliah E (2020) Neuroinflammation is associated with infiltration of T cells in Lewy body disease and $\alpha$-synuclein transgenic models. J Neuroinflammation 17, 214.

[33] Sommer A, Maxreiter F, Krach F, Fadler T, Grosch J, Maroni M, Graef D, Eberhardt E, Riemenschneider MJ, Yeo GW, Kohl Z, Xiang W, Gage FH, Winkler J, Prots I, Winner B (2018) Th17 lymphocytes induce neuronal cell death in a human iPSC-based model of Parkinson's disease. Stem Cell 23, 123-131.e6.

[34] Theodore S, Cao S, McLean PJ, Standaert DG (2008) Targeted overexpression of human $\alpha$-synuclein triggers microglial activation and an adaptive immune response in a mouse model of Parkinson disease. J Neuropathol Exp Neurol 67, 1149-1158.

[35] Olesen MN, Christiansen JR, Petersen SV, Jensen PH, Paslawski W, Romero-Ramos M, Sanchez-Guajardo V (2018) CD4 T cells react to local increase of $\alpha$-synuclein in a pathology-associated variant-dependent manner and modify brain microglia in absence of brain pathology. Heliyon 4, $\mathrm{e} 00513$.

[36] Harms AS, Cao S, Rowse AL, Thome AD, Li X, Mangieri LR, Cron RQ, Shacka JJ, Raman C, Standaert DG (2013) MHCII is required for $\alpha$-synuclein-induced activation of microglia, CD4 $\mathrm{T}$ cell proliferation, and dopaminergic neurodegeneration. J Neurosci 33, 95929600 .

[37] Subbarayan MS, Hudson C, Moss LD, Nash KR, Bickford PC (2020) T cell infiltration and upregulation of MHCII in microglia leads to accelerated neuronal loss in an $\alpha$ -synuclein rat model of Parkinson's disease. J Neuroinflammation 17, 242.

[38] Mundt S, Greter M, Flügel A, Becher B (2019) The CNS immune landscape from the viewpoint of a $\mathrm{T}$ cell. Trends Neurosci 42, 667-679.

[39] Shultz LD, Lyons BL, Burzenski LM, Gott B, Chen X, Chaleff S, Kotb M, Gillies SD, King M, Mangada J, Greiner DL, Handgretinger R (2005) Human lymphoid and myeloid cell development in NOD/LtSz-scid IL2R $\gamma$ null mice engrafted with mobilized human hemopoietic stem cells. J Immunol 174, 6477-6489.

[40] Volpicelli-Daley LA, Luk KC, Lee VMY (2014) Addition of exogenous $\alpha$-synuclein preformed fibrils to primary neuronal cultures to seed recruitment of endogenous $\alpha$ synuclein to Lewy body and Lewy neurite-like aggregates. Nat Protoc 9, 2135-2146.

[41] Becker K, Wang X, Stel K vander, Chu Y, Kordower J, Ma J (2018) Detecting alpha synuclein seeding activity in formaldehyde-fixed MSA patient tissue by PMCA. Mol Neurobiol 55, 8728-8737.

[42] Paxinos G, Franklin KBJ (2001) The mouse brain in stereotaxic coordinates, compact. $3^{\text {rd }}$ ed. Academic Press, Massachusetts.

[43] Zuccarino-Catania G, Shlomchik M (2015) Adoptive transfer of memory B cells. Bio-protocol 5, e1563.

[44] Gautreaux MD, Gelder FB, Deitch EA, Berg RD (1995) Adoptive transfer of T lymphocytes to T-cell-depleted mice inhibits Escherichia coli translocation from the gastrointestinal tract. Infect Immun 63, 3827-3834.

[45] Reynolds AD, Stone DK, Hutter JAL, Benner EJ, Mosley RL, Gendelman HE (2010) Regulatory T cells attenuate Th17 cell-mediated nigrostriatal dopaminergic 
neurodegeneration in a model of Parkinson's disease. $J$ Immunol 184, 2261-2271.

[46] Ashman RB (2012) Leucocytes: Methods and protocols.

[47] Kawahara T, Ohdan H, Zhao G, Yang Y-G, Sykes M, Cells NA (2003) Peritoneal cavity B cells are precursors of splenic IgM natural antibody-producing cells. J Immunol 171, 5406-5414.

[48] Klenovsek K, Weisel F, Schneider A, Appelt U, Jonjic S, Messerle M, Bradel-Tretheway B, Winkler TH, Mach M (2007) Protection from CMV infection in immunodeficient hosts by adoptive transfer of memory B cells. Blood $\mathbf{1 1 0}$, 3472-3479.

[49] Beach TG, Adler CH, Lue L, Sue LI, Bachalakuri J, HenryWatson J, Sasse J, Boyer S, Shirohi S, Brooks R, Eschbacher J, White CL, Akiyama H, Caviness J, Shill HA, Connor DJ, Sabbagh MN, Walker DG (2009) Unified staging system for Lewy body disorders: Correlation with nigrostriatal degeneration, cognitive impairment and motor dysfunction. Acta Neuropathol 117, 613-634.

[50] Beach TG, White CL, Hamilton RL, Duda JE, Iwatsubo T, Dickson DW, Leverenz JB, Roncaroli F, Buttini M, Hladik CL, Sue LI, Noorigian JV, Adler CH (2008) Evaluation of $\alpha$-synuclein immunohistochemical methods used by invited experts. Acta Neuropathol 116, 277-288.

[51] George S, Rey NL, Tyson T, Esquibel C, Meyerdirk L, Schulz E, Pierce S, Burmeister AR, Madaj Z, Steiner JA, Galvis MLE, Brundin L, Brundin P (2019) Microglia affect $\alpha$-synuclein cell-to-cell transfer in a mouse model of Parkinson's disease. Mol Neurodegen 14, 1-22.

[52] Nalls MA, Blauwendraat C, Vallerga CL, Heilbron K, Bandres-Ciga S, Chang D, Tan M, Kia DA, Noyce AJ, Xue A, et al. (2019) Identification of novel risk loci, causal insights, and heritable risk for Parkinson's disease: A metaanalysis of genome-wide association studies. Lancet Neurol 18, 1091-1102.

[53] Williams GP, Marmion DJ, Schonhoff AM, Jurkuvenaite A, Won WJ, Standaert DG, Kordower JH, Harms AS (2020) T cell infiltration in both human multiple system atrophy and a novel mouse model of the disease. Acta Neuropathol 139, 855-874.

[54] Schetters STT, Gomez-Nicola D, Garcia-Vallejo JJ, van Kooyk Y (2018) Neuroinflammation: Microglia and T cells get ready to tango. Front Immunol 8, 1905.

[55] Lindestam Arlehamn CS, Garretti F, Sulzer D, Sette A (2019) Roles for the adaptive immune system in Parkinson's and Alzheimer's diseases. Curr Opin Immunol 59, 115-120.

[56] Williams GP, Schonhoff AM, Jurkuvenaite A, Thome AD, Standaert DG, Harms AS (2018) Targeting of the class II transactivator attenuates inflammation and neurodegeneration in an alpha-synuclein model of Parkinson's disease. $J$ Neuroinflammation 15, 244.

[57] Thome AD, Harms AS, Volpicelli-Daley LA, Standaert DG (2016) microRNA-155 regulates alpha-synuclein-induced inflammatory responses in models of Parkinson disease. $J$ Neurosci 36, 2383-2390.

[58] van der Perren A, Toelen J, Casteels C, Macchi F, van Rompuy A-S, Sarre S, Casadei N, Nuber S, Himmelreich U, Osorio Garcia MI, Michotte Y, D'Hooge R, Bormans G, van Laere K, Gijsbers R, van den Haute C, Debyser Z, Baekelandt V (2015) Longitudinal follow-up and characterization of a robust rat model for Parkinson's disease based on overexpression of alpha-synuclein with adeno-associated viral vectors. Neurobiol Aging 36, 1543-1558.

[59] Sommer A, Fadler T, Dorfmeister E, Hoffmann A-C, Xiang W, Winner B, Prots I (2016) Infiltrating T lymphocytes reduce myeloid phagocytosis activity in synucleinopathy model. J Neuroinflammation 13, 174.

[60] Luk KC, Covell DJ, Kehm VM, Zhang B, Song IY, Byrne MD, Pitkin RM, Decker SC, Trojanowski JQ, Lee VMY (2016) Molecular and biological compatibility with host alpha-synuclein influences fibril pathogenicity. Cell Reports 16, 3373-3387.

[61] Orr CF, Rowe DB, Mizuno Y, Mori H, Halliday GM (2005) A possible role for humoral immunity in the pathogenesis of Parkinson's disease. Brain 128, 2665-2674.

[62] Reynolds AD, Stone DK, Mosley RL, Gendelman HE (2009) Nitrated $\alpha$-synuclein-induced alterations in microglial immunity are regulated by $\mathrm{CD} 4+\mathrm{T}$ cell subsets. J Immunol 182, 4137-4149.

[63] Grabert K, Michoel T, Karavolos MH, Clohisey S, Baillie JK, Stevens MP, Freeman TC, Summers KM, McColl BW (2016) Microglial brain region-dependent diversity and selective regional sensitivities to aging. Nat Neurosci 19, 504-516.

[64] Lawson LJ, Perry VH, Dri P, Gordon S (1990) Heterogeneity in the distribution and morphology of microglia in the normal adult mouse brain. Neurosci 39, 151-170.

[65] Geirsdottir L, David E, Keren-Shaul H, Weiner A, Bohlen SC, Neuber J, Balic A, Giladi A, Sheban F, Dutertre CA, Pfeifle C, Peri F, Raffo-Romero A, Vizioli J, Matiasek K, Scheiwe C, Meckel S, Mätz-Rensing K, Meer F van der, Thormodsson FR, Stadelmann C, Zilkha N, Kimchi T, Ginhoux F, Ulitsky I, Erny D, Amit I, Prinz M (2019) Cross-species single-cell analysis reveals divergence of the primate microglia program. Cell 179, 1609- 1622.e16.

[66] Mundt S, Mrdjen D, Utz SG, Greter M, Schreiner B, Becher B (2019) Conventional DCs sample and present myelin antigens in the healthy CNS and allow parenchymal T cell entry to initiate neuroinflammation. Sci Immunol 4, eaau8380.

[67] Harms AS, Thome AD, Yan Z, Schonhoff AM, Williams GP, Li X, Liu Y, Qin H, Benveniste EN, Standaert DG (2018) Peripheral monocyte entry is required for alpha-Synuclein induced inflammation and Neurodegeneration in a model of Parkinson disease. Exp Neurol 300, 179-187.

[68] Martino AT, Markusic DM (2020) Immune response mechanisms against AAV vectors in animal models. Mol Ther Methods Clin Dev 17, 198-208.

[69] Oliveras-Salvá M, van der Perren A, Casadei N, Stroobants S, Nuber S, D'Hooge R, van den Haute C, Baekelandt V (2013) RAAV2/7 vector-mediated overexpression of alpha-synuclein in mouse substantia nigra induces protein aggregation and progressive dose-dependent neurodegeneration. Mol Neurodegener 8, 1-14.

[70] Luk KC, Kehm VM, Zhang B, O’Brien P, Trojanowski JQ, Lee VMY (2012) Intracerebral inoculation of pathological $\alpha$-synuclein initiates a rapidly progressive neurodegenerative $\alpha$-synucleinopathy in mice. J Exp Med 209, 975-986.

[71] Zhang W, Wang T, Pei Z, Miller DS, Wu X, Block ML, Wilson B, Zhang W, Zhou Y, Hong J-S, Zhang J (2005) Aggregated $\alpha$-synuclein activates microglia: A process leading to disease progression in Parkinson's disease. FASEB J 19, 533-42.

[72] Choi I, Zhang Y, Seegobin SP, Pruvost M, Wang Q, Purtell K, Zhang B, Yue Z (2020) Microglia clear neuron-released $\alpha$-synuclein via selective autophagy and prevent neurodegeneration. Nat Commun 11, 1386.

[73] Villadiego J, Labrador-Garrido A, Franco JM, Leal-Lasarte M, de Genst EJ, Dobson CM, Pozo D, Toledo-Aral JJ, Roodveldt C (2018) Immunization with $\alpha$-synuclein/Grp94 
reshapes peripheral immunity and suppresses microgliosis in a chronic Parkinsonism model. Glia 66, 191-205.

[74] Lemos M, Venezia S, Refolo V, Heras-Garvin A, Schmidhuber S, Giese A, Leonov A, Ryazanov S, Griesinger C, Galabova G, Staffler G, Wenning GK, Stefanova N (2020) Targeting $\alpha$-synuclein by PD03 AFFITOPE $®$ and Anle138b rescues neurodegenerative pathology in a model of multiple system atrophy: Clinical relevance. Transl Neurodegener 9, 38 .

[75] Christiansen JR, Olesen MN, Otzen DE, Romero-Ramos M, Sanchez-Guajardo V (2016) $\alpha$-Synuclein vaccination modulates regulatory $\mathrm{T}$ cell activation and microglia in the absence of brain pathology. J Neuroinflammation 13, 74 .

[76] Mandler M, Valera E, Rockenstein E, Mante M, Weninger H, Patrick C, Adame A, Schmidhuber S, Santic R, Schneeberger A, Schmidt W, Mattner F, Masliah E (2015) Active immunization against alpha-synuclein ameliorates the degenerative pathology and prevents demyelination in a model of multiple system atrophy. Mol Neurodegener 10, 721.

[77] Romero-Ramos M, Chelpin MVE, Sanchez-Guajardo V (2014) Vaccination strategies for Parkinson disease:
Induction of a swift attack or raising tolerance? Hum Vaccines Immunother 10, 852-867.

[78] Caligiuri MA (2008) Human natural killer cells. Blood 112, 461-469.

[79] Hao J, Liu R, Piao W, Zhou Q, Vollmer TL, Campagnolo DI, Xiang R, Cava A la, Kaer L van, Shi F-D (2010) Central nervous system (CNS)-resident natural killer cells suppress Th17 responses and CNS autoimmune pathology. J Exp Med 207, 1907-1921.

[80] Mihara T, Nakashima M, Kuroiwa A, Akitake Y, Ono K, Hosokawa M, Yamada T, Takahashi M (2008) Natural killer cells of Parkinson's disease patients are set up for activation: A possible role for innate immunity in the pathogenesis of this disease. Parkinsonism Relat Disord 14, 46-51.

[81] Earls RH, Menees KB, Chung J, Gutekunst C-A, Lee HJ, Hazim MG, Rada B, Wood LB, Lee J-K (2020) NK cells clear $\alpha$-synuclein and the depletion of NK cells exacerbates synuclein pathology in a mouse model of $\alpha$ synucleinopathy. Proc Natl Acad Sci U S A 117, 1762-1771.

[82] Marsden MD, Zack JA (2017) Humanized mouse models for human immunodeficiency virus infection. Annu Rev Virol 4, 393-412. 